Post-proof copy of

M. J. Zeeman, H. Shupe, C. Baessler, and N. K. Ruehr.

"Productivity and vegetation structure of three differently managed temperate grasslands"

5 In: Agriculture, Ecosystems \& Environment 270-271 (Feb. 2019), pp. 129-148.

DOI: 10.1016/j.agee.2018.10.003 


\section{Productivity and vegetation structure of three differently managed temperate grasslands}

Matthias J. Zeeman ${ }^{1}$, Heather Shupe ${ }^{2}$, Cornelia Baessler ${ }^{3}$, Nadine K. Ruehr ${ }^{1}$

${ }^{1}$ Karlsruhe Institute of Technology, Institute of Meteorology and Climate Research, Atmospheric Environmental

5 Research, Garmisch-Partenkirchen, Germany

${ }^{2}$ University of Hamburg, Biocenter Klein Flottbek - Applied Plant Ecology, Hamburg, Germany

${ }^{3}$ Helmholtz Centre for Environmental Research (UFZ), Department Community Ecology, Halle, Germany

Correspondence to: Matthias Zeeman (matthias.zeeman@kit.edu)

\section{Abstract.}

An improved regional assessment of the productivity of grasslands depends on comprehensive knowledge of the interactions between climatic drivers, vegetation properties and human activity. Managed grasslands in Europe display highly dynamic responses, which contribute to the challenge in making representative model simulations.

15 Therefore, we investigated the relationships between vegetation state changes and productivity of meadow grasslands by comparing three study sites in Southern Germany (DE-Fen, DE-RbW, DE-Gwg), which are characterised by different management intensities and elevations. Weekly observations of vegetation height, leaf area, aboveground biomass and plant functional types were compared to estimates of the gross

20 ecosystem productivity (GEP) determined from atmospheric surface exchange of carbon dioxide. We found that the cumulative GEP of these grasslands correlated positively with management intensity and negatively with elevation at the seasonal scale. The differences in above-ground vegetation properties among the three sites were most pronounced during spring and contributed to significant differences in annual carbon (200\%) and

25 nitrogen (4\%) biomass yields. Nevertheless, when periods between harvests were 
considered individually, the relationship between GEP and above-ground biomass, leaf area and vegetation height appeared to follow unified patterns for all sites. In addition, our study highlights a substantial potential for systematic error based on the techniques used to quantify vegetation properties and a mitigating approach was evaluated that

5 includes continuous automated observations of vegetation height. These outcomes can serve as a reference for modelling studies on the seasonal allocation of carbon and vegetation properties in managed humid temperate grassland systems.

Keywords: canopy structure; LAI; above-ground biomass; land use; NEE; GEP; carbon cycle; biodiversity

\section{INTRODUCTION}

Temperate grasslands are a major terrestrial biome with the potential to act as a sink for atmospheric carbon dioxide (Baldocchi, 2008). The uptake of atmospheric carbon dioxide $\left(\mathrm{CO}_{2}\right)$ by temperate grasslands is closely linked to vegetation dynamics, which are driven

15 by seasonality and management practices (Scurlock et al., 2002). Regional estimates may confirm this role for European grasslands, but at the same time give emphasis to the uncertainty that ensues from the complex interplay between changes in management practice, energy and nutrient cycles and regional climate variability (Janssens et al., 2003; Gilmanov et al., 2007; Soussana et al., 2007b; Chang et al., 2015). A reduction in

20 uncertainty may be achieved through the assessment of spatio-temporal changes in the vegetation using remote sensing and models. However, such a scale increase requires detailed knowledge about the relationships between vegetation properties, productivity 
and the dynamics of land surface-atmosphere exchange, which in first place must be postulated from evidence at the site level.

Temperate grasslands typically show rapidly changing phenology throughout the season, which is further modulated by management practices (Figure 1). The seasonal 5 development of the vegetation can be observed from state changes in vegetation height, leaf area, biomass and phenology, although above-ground changes are only part of what influences the interactions between an ecosystem and the atmosphere above. The uptake and release of $\mathrm{CO}_{2}$ are linked to growth, respiration and allocation (metabolism, consumption, storage) in the above- and below-ground pools of the ecosystem. For

10 managed ecosystems we could further distinguish in situ and ex situ pools, for instance, where biomass from the meadows (in situ) is harvested for use elsewhere and may only partly return as fertilizer mass later. The in situ $\mathrm{CO}_{2}$ exchange of a managed grassland ecosystem can be observed using the Eddy Covariance (EC) technique, by which surface uptake and release of $\mathrm{CO}_{2}$ are recorded mixed and locally integrated over space and time 15 as Net Ecosystem Exchange (NEE). From the NEE we can determine the magnitudes of underlying component fluxes using a framework of assumptions and empirical models that allow partitioning of the NEE in Ecosystem Respiration $\left(\mathrm{R}_{\mathrm{eco}}\right)$ and Gross Ecosystem Production (GEP), the component fluxes that are directed away from and towards the surface, respectively (Aubinet et al., 2012). The Gross Ecosystem Production (GEP) is a 20 flux measure for the carbon (C) assimilation activity of the vegetation via photosynthesis. Photochemical and biochemical reactions occur under input of light, water and nutrients, but are further influenced by environmental conditions and plant phenology. Firstly, the GEP is correlated to the abundance of incoming photosynthetically usable ambient light, which is primarily modulated over the course of the season and the day by solar zenith 
angle, day length and surfaces (clouds) that reflect and diffuse the light. Secondly, the efficiency of the vegetation in using the incoming radiation relates to leaf area and canopy structure after acclimation (Lichtenthaler et al., 1981; Evans and Poorter, 2001), if water and nutrient supplies are sufficient and other stress factors are absent. This implies that

5 GEP and above-ground plant properties will tend to auto-correlate in well-established, hydrated and fertilized grasslands as found in large parts of Europe. However, the GEP does not provide direct information about the allocation of $\mathrm{C}$ in plants; be it for use in maintenance, growth or storage in either the above-ground or the below-ground compartment. Further, GEP is influenced by environmental drivers that show variability

10 and seasonality that may be particular to the climate at a specific locality, including radiation, humidity and temperature. Because GEP represents the integration of such process drivers, as well as the cross-dependencies between those process drivers and vegetation states throughout the season, it represents a meaningful signal of ecosystem activity over time. Observation of ecosystems along elevation gradients allows us to study

15 the impact of environmental drivers, framed by regional climate, weather and management, on biochemical and biophysical processes that ultimately govern changes and differences in vegetation (Gilgen and Buchmann, 2009; Zeeman et al., 2010).

The objectives of this study were to quantify the relationships between above-ground vegetation properties and productivity of managed humid temperate grasslands in 20 continental Europe and to determine how these relationships were affected by differences in elevation and management. We studied the relationships between above-ground vegetation state changes and $\mathrm{C}$ exchange fluxes of temperate grasslands at three sites along an elevational gradient from pre-alpine foothills towards the Alps, coinciding with intensive- to extensive management. The impacts of observation frequency on the 
outcomes were studied by contrasting daily non-intrusive vegetation height samples to traditional weekly surveys.

\section{MATERIALS AND METHODS}

\section{$5 \quad 2.1 \quad$ FIELD SITES}

This experiment took place at the field sites Fendt (DE-Fen, $47.8329^{\circ} \mathrm{N} 11.0607^{\circ} \mathrm{E}, 595$ $\mathrm{m}$ above mean sea level), Rottenbuch (DE-Rbw, $47.7299^{\circ} \mathrm{N} 10.9690^{\circ} \mathrm{E}, 769 \mathrm{~m}$ a.m.s.1.) and Graswang (DE-Gwg, 47.5708 ${ }^{\circ} \mathrm{N} 11.0326^{\circ} \mathrm{E}, 864 \mathrm{~m}$ a.m.s.1.) in Southern Germany. These sites belong to the German Terrestrial Environmental Observatories (TERENO)

10 network (Zacharias et al., 2011; Kiese et al., 2018). The Fendt site is situated at the valley floor of the Rott stream tributary, the Rottenbuch site is situated just east of the Ammer river on a former river bed and the Graswang site is situated in the east-west oriented valley of the Linder tributary to the Ammer river and is surrounded by the Ammergauer Alps. The land is used for fodder production at all sites, with the addition of grazing by

15 wildlife in fall, mostly by deer foraging from the forested mountain area surrounding the Graswang site. The region is shaped by glacial and periglacial processes that formed the alpine foothills and left moraines, deposited sediment and allowed buildup of organic matter in the soil (Wang et al., 2016). The rich soils stimulated the development of agriculture in the region, including animal husbandry, predating the industrial age.

\section{$20 \quad 2.2$ OBSERVATIONS OF VEGETATION DYNAMICS}

Vegetation dynamics at the study sites were observed during the growing season of 2015 (2 April to 30 October 2015), which coincided with the multi-scale field campaign ScaleX 2015 (Wolf et al., 2017). Changes in plant area, above-ground biomass and height of the 
vegetation at the three grassland sites were measured using destructive and nondestructive methods.

Changes in plant area index (PAI) of all three sites were assessed at weekly intervals until September and bi-weekly thereafter (in total 27 one-day measurement campaigns in 5 2015). The effective plant area index ( $\left.\mathrm{PAI}_{\mathrm{eff}}\right)$ was measured using a leaf area meter (LAI2200, LiCor, Lincoln, NE, USA). A viewing cap on the sensor lens with a $90^{\circ}$ opening excluded the observer from the half-hemispheric view towards the sky at zenith angle, while the observations were made such that the observer's shadow was cast on the sensor and sampled area. The PAI $\mathrm{P}_{\text {eff }}$ was computed based on light level differences observed

10 above the canopy and within the canopy at approximately $0.02 \mathrm{~m}$ above the surface. Measurements were made in transects of at least $5 \mathrm{~m}$, by moving the sensor head forward at ground level. This allowed for observations of canopy light levels every $0.3 \mathrm{~m}$, with minimal distortion of the canopy above the sensor. With this method we cannot exclude area of non-photosynthesizing tissue from the $\mathrm{PAI}_{\text {eff }}$ observations as consistently as for

15 deciduous forests, i.e., by subtracting wintertime estimates of trunk and branch area. However, we expect the non-photosynthesizing area, i.e., flowers, to be relatively small compared to the area of leaves and green stems at these grassland study sites. We continue here using the term PAI instead of Leaf Area Index (LAI), although the terms can be found used as synonyms elsewhere.

20 On most occasions, the $\mathrm{PAI}_{\text {eff }}$ measurements were supplemented with destructive biomass sampling to determine above-ground biomass (AGB) and PAI. In brief, a 0.30 $\mathrm{m} \times 0.30 \mathrm{~m}$ sample area frame was placed randomly at 5 locations within $5-20 \mathrm{~m}$ of the EC station, in an area representative of the EC footprint (Zeeman et al., 2017). First, vegetation height $\left(h_{c-m}\right)$ was measured from a standard area (paper sample bag; $0.23 \mathrm{~m}$ 
$\mathrm{x} 0.32 \mathrm{~m}, 11 \mathrm{~g}$ ) placed on top of the vegetation and the maximum vegetation height was recorded if the compression by the area appeared large. Second, all vegetation above 0.07 $\mathrm{m}$ height was sampled. Third, a second biomass sample was taken from 0.02 to $0.07 \mathrm{~m}$, representing the residual above-ground vegetation below the typical machine harvest

5 height. The vegetation between 0.00 and $0.02 \mathrm{~m}$ was not sampled. This was a practical consideration in order to avoid collecting litter and soil along with the plant samples and to match the PAI samples to the viewing range of the leaf are meter observations of $\mathrm{PAI}_{\mathrm{eff}}$ as it was used in the field. The samples were kept cool and transported to the lab where they were stored at $4{ }^{\circ} \mathrm{C}$ until further processing. First, the vegetation samples were 10 separated in functional groups (FGs) 'grass', 'clover', 'herbaceous', 'herbaceous flowers', 'moss' and 'unspecified' biomass material. Second, the PAI was determined for each FG subsample using a benchtop leaf area meter (Li-3100C, LiCor, Lincoln, NE, USA). These measurements were used to calibrate the PAI $\mathrm{Iff}_{\text {ff }}$ measurements, which were measured slightly more often during the season (see Appendix C). In addition, pictures

15 of small subsamples per FG were taken and analyzed using Image (version 1.3, National Institute of Health, USA; Schneider et al., 2012) to determine the specific leaf area (SLA). Information of SLA was in turn used to correct a Li-3100C measurement bias, caused by minor sample overlap (see Appendix C). Third, all samples were oven-dried at $60^{\circ} \mathrm{C}$ for 48 hours before dry weight (DW) was determined. Finally, the C/N-ratios of each FG 20 were determined for samples collected on seven days during the season for each site, totaling 50 samples. No significant differences were found in the $\mathrm{C}$ content among the FGs. Therefore, the average $\mathrm{C}$ content measured from the samples $(43.47 \pm 1.8 \%)$ was used to calculate aboveground biomass $\mathrm{C}$ content in units of $\left[\mathrm{gC} \mathrm{m}^{-2}\right]$. 
Vegetation height $\left(h_{c-a}\right)$ was observed continuously using a sonic range sensor (SR50A; Campbell Scientific, Logan, UT, USA) at each study site, providing contact-less depth information every $1 \mathrm{~min}$ at $0.01 \mathrm{~m}$ resolution with a circular ground view of approximately $1.1 \mathrm{~m}$ diameter. All measurements were temperature corrected following

5 the manufacturer's recommendation and the data was filtered for noise. The sensor has been successfully applied to measure vegetation height (e.g., Jørgensen et al., 2011) and automated measurements were additionally verified by the field survey measurements $\left(h_{c-m}\right)$ on a weekly-basis (see Appendix C).

\subsection{EC DATA PROCESSING AND STATISTICAL ANALYSIS}

10 At all three sites, surface exchange fluxes with the atmosphere were observed since 2010. Carbon dioxide exchange with the atmosphere was calculated for each half-hour using the eddy covariance technique and site-specific computational procedures described in detail by Mauder et al. (2013) and Zeeman et al. (2017). Our procedure followed the methodology of previous studies on $\mathrm{C}$ exchange of temperate grasslands in mountainous

15 terrain in proximity to the Alps (Ammann et al., 2007; Zeeman et al., 2010). Measurements of the NEE were parameterized with soil temperature and photosynthetically active radiation (PAR) using empirical models for ecosystem respiration $\left(R_{\text {eco }}\right)$ and gross ecosystem productivity (GEP), assuming a flux balance equation where NEE $=$ GEP $+R_{\text {eco }}$ (Lloyd and Taylor, 1994; Falge et al., 2001;

20 Flanagan et al., 2002; Aubinet et al., 2012). The cumulative sums of NEE ( $\sum$ NEE) and GEP ( $\sum$ GEP) were computed after imputation of missing values, relying on the NEE observations and empirical model outcomes for each 30-min interval. The atmospheric exchange flux results are reported here in units $\left[\mathrm{gC} \mathrm{m}^{-2}\right]$ with the negative signs towards the surface. We focus on in situ $\mathrm{C}$ pools, which means that we exclude $\mathrm{CO}_{2}$ exchange 
resulting from any ex situ consumption of biomass, i.e., the $\mathrm{C}$ mass reductions between the transport of biomass from the land and the partial return as organic fertilizer. For the computation of $\mathrm{C}$ exchange fluxes in this study, we ignored the surface exchange of other molecules containing $\mathrm{C}$, such as methane, volatile organic $\mathrm{C}$ and dissolved organic $\mathrm{C}$, as 5 well as any fraction of the managed depositions of organic fertilizer that are not accounted for as respired $\mathrm{CO}_{2}$ in the exchange flux observations.

The AGB and PAI observations reported here represent vegetation above $0.02 \mathrm{~m}$, whereas the whole canopy is systematically included in observations of $h_{c}$ and the exchange fluxes. In principle, we could interpolate the AGB and PAI observations in the 0.02 to $100.07 \mathrm{~m}$ range as an estimate of the complete residual AGB that includes the stubs and surface dwelling plants, but that would inadvertently introduce a complex of uncertainties.

Relationships between vegetation parameters (height, AGB and PAI) and NEE or GEP were determined using three basic regression models to fit the relationships between the 15 recorded variables, which can be classified as, Eq. $1-3$,

$$
\begin{aligned}
& \hat{y}_{\mathrm{p}}=\alpha_{1}+\alpha_{2} \cdot x \\
& \hat{y}_{\mathrm{p}}=\beta_{1} /\left(1+\mathrm{e}^{\left(\beta_{2}-x\right) / \beta_{3}}\right) \\
& \hat{y}_{\mathrm{p}}=\gamma_{1}+\left(\gamma_{2}-\gamma_{1}\right) \mathrm{e}^{-\gamma_{3} \cdot x}
\end{aligned}
$$

a linear, a logistic and asymptotic model, respectively. The models were used in conjunction with plotted regressions, where for each variable on the ordinate $(y)$ the relationship for the modelled representation $(\hat{y})$ is given as a function of the variable on

20 the abscissa $(x)$. The right-hand model parameters represent the offset $\left(\alpha_{1}\right)$, the slope 
$\left(\alpha_{2}\right)$, the right-side horizontal asymptote $\left(\beta_{1}, \gamma_{1}\right)$, the inflection point along the $x$ axis $\left(\beta_{2}\right)$ where $\left\{\hat{y}=\beta_{1} / 2\right\}$, the scale along the $x$ axis $\left(\beta_{3}\right)$, the response $\left(\gamma_{2}\right)$ where $\{x=0\}$ and a rate constant $\left(\gamma_{3}\right)$. The subscript $(p)$ denotes a management period classification, where we distinguish the first management period of the season (I), regular management

5 periods (II) and periods with grazing (III). Data analyses were made using statistical computing software R ( $\mathrm{R}$ version 3.5.0; R Development Core Team, 2018).

\section{RESULTS}

\subsection{ENVIRONMENTAL CONDITIONS}

The three study sites differ in elevation, resulting in differences in environmental

10 conditions at the sites. The climate records from the weather stations near the low elevation site Fendt showed that the months May and June in 2015 were significantly wet, and July and August were dry and hot (see Appendix A). Compared to the lowest elevation, the mean air temperature during March to November 2015 was 1.6 degrees Kelvin $(\mathrm{K})$ and 2.0 degrees $\mathrm{K}$ lower at the middle and highest elevation, respectively.

15 This trend did not change during July and August (gradient of 1.9 degrees K). Although the total precipitation was similar at the three elevations over the growing season period, the highest elevation received $58 \%(158 \mathrm{~mm})$ more precipitation during July and August than the lower two elevations. This difference in summer precipitation may be explained by differences in terrain, in addition to elevation, where particularly at the highest site the

20 surrounding topography increases the chance of precipitation by orographic lift.

\subsection{VEGETATION AND MANAGEMENT}

The sites differ in plant species composition because only 18 of the 59 observed plant species (32\%) occurred at all three sites (see Appendix B). Rottenbuch was the site with 
the lowest biodiversity (20 species, Graswang: 37 species, Fendt: 45 species; see Appendix B). The average of the ecological indicator values (Ellenberg et al., 1992; Diekmann, 2003; Bartelheimer and Poschlod, 2016) of plant species provided an estimate of the prevailing environmental conditions at the study sites (Table 1). Following 5 Ellenberg et al. (1992), the temperature value (T) and humidity number (F), derived from the species composition at each study site, indicates typical temperate-submontane conditions and moderately moist soils. Considering the nutrient value $(\mathrm{N})$ and the soil reaction $(\mathrm{R})$, the three study sites show a moderate to high nutrient availability and moderately to weakly acidic soils. The study site Rottenbuch showed a slightly higher $\mathrm{N}$

10 and $\mathrm{R}$ number, suggesting an increased nutrient availability and a less acidic soil compared to Graswang and Fendt (Table 1). This, in addition to the lower plant biodiversity, but higher mowing compatibility and higher feeding value (Briemle et al., 2002), indicated a more intensive farming at the Rottenbuch site. Fendt and Graswang were additionally characterized by species (Bistorta officinalis, Lychnis flos-cuculi,

15 Ranunculus repens), which prefer more moist and nutrient poor habitats. Furthermore, the species that occurred only in Graswang, such as Dactylorhiza maculata and Leucanthemum vulgare, are typically found only in nutrient poor habitats and thus speak for a more extensive land use, in agreement with the frequency of harvest at this study site (Table 1 and Table 2; see also Appendix B). As manifested in plant species and 20 diversity, the three sites differ in management regimes, where the lower elevation sites Rottenbuch and Fendt were cut five times a year and the high elevation site Graswang was cut twice and grazed by free range deer in late summer and autumn (Table 2). Slurry manure was applied to the field as organic fertilizer before spring (March), following most harvests and before winter (November) at the two lower study sites, Rottenbuch and

25 Fendt, but not at the highest study site, Graswang. The organic fertilizer application dates 
(day of year; DOY) were 078, 133, 169, 204 and 245 and 072, 138, 190 and 259 for Rottenbuch and Fendt, respectively.

In addition to species composition, also the seasonal variation in abundance per plant functional type (here vegetation was divided into grasses, clover, other herbaceous 5 species, flowers and mosses) revealed clear differences between the sites (Figure 2). First, grasses dominated the sampled AGB immediately after winter dormancy and in the first weeks after most harvests. Second, the abundance of clover was highest at the lowest elevation (Figure 2c) and lowest at the highest elevation site (Figure 2a), both in absolute amount and relative to the total biomass. In the second half of July, the abundance of

10 clover even equaled or surpassed that of grasses at the lowest elevation. Third, between April and May, during the last weeks of the first management period, herbaceous flowering plants made a sudden appearance at the two lower elevations. This appearance was dominated by dandelion (Taraxacum sect. Ruderalia.). The AGB decreased after reaching a maximum in the first week of June at the highest elevation, which appeared to

15 coincide with a decrease in grasses (Figure 2).

\subsection{PRODUCTIVITY}

The management regimes and climatic (elevation) differences were reflected in the productivity, which refers to overall yield (biomass) as well as $\mathrm{C}$ uptake (cumulative sum of atmospheric exchange). The lowest elevation site showed the largest magnitude in

20 growing season ecosystem productivity and respiration fluxes, as well as the largest harvested AGB (Table 2). At all elevations, the harvested biomass ( $\left.\mathrm{AGB}_{\text {cut }}\right)$ can be explained by atmospheric $\mathrm{CO}_{2}$ uptake (Table 2; GEP, NEE less significant). The second half of the season showed no significant net atmospheric $\mathrm{CO}_{2}$ uptake (or loss) at any of the sites (Table 2 and Figure 5). Although a similar yield of approximately $100 \mathrm{~g} \mathrm{~m}^{-2}$ was 
harvested during the first periods at the highest and lowest sites, the mass gain was achieved in less time and earlier in the year at the lowest elevation (sixteen days less; sixteen days earlier). As a result, the annual sums of $\mathrm{C}$ and $\mathrm{N}$ in $\mathrm{AGB}_{\text {cut }}$ were almost twice as high at the lowest elevation, Fendt, than at the highest elevation, Graswang (Table 2).

5 The residual $A G B$ after the cuts $\left(\mathrm{AGB}_{\text {res }}\right)$ showed a peak in August at all sites. At the lowest and highest elevation, the $\mathrm{AGB}_{\text {cut }}$ decreased towards the end of the season. The difference between AGB and GEP over the season at the highest elevation could be attributed to grazing. The differences in the species composition (functional groups) between the sites contributed significantly to the amount of $\mathrm{N}$ in the AGB. Approximately

$104 \%$ more $\mathrm{N}$ was collected in the biomass at the lowest elevation site compared to the highest elevation, which was attributed to a higher clover abundance in combination with a higher $\mathrm{N}$ content of clover.

\subsection{VEGETATION STRUCTURE DYNAMICS}

The seasonality in management, species composition and phenology was manifested in

15 the vegetation structure. First, the onset of the growing season differed between the three sites (Figure 3). At the end of winter and before growth was recorded, the vegetation at Graswang, the highest elevation site, showed the lowest vegetation height $(0.02 \mathrm{~m})$ which suggests that the vegetation had been compressed under snow pack load during winter (data not shown, but for an example see Figure 3 late Nov 2015 and Figure 1). A few

20 days of snow pack are visible in mid-March at the highest elevation and during a cold spell at the start of April at the Rottenbuch and Grasang sites, the middle and highest elevations, respectively, but not at Fendt, the low elevation site (Figure 3a; indicated by the automatic height measurements). The first significant changes in $h_{c}$, defined here where $h_{c-a}$ exceeded $0.07 \mathrm{~m}$, occurred on 11, 16 and 27 April 2015 from lowest to 
highest elevation, respectively. Thereafter, vegetation increased in height until the first harvest took place in mid-May at the two lower elevation sites and in mid-June at highest elevation site. Growth at the highest elevation site started later in the season (16 days later) and the growth period was longer (16 days longer) than at the lowest elevation site,

5 leading to an increase in $h_{c}$ up to a maximum of approximately $0.6 \mathrm{~m}$ and a PAI of approximately 5, before decreasing slightly until harvest (Table 2 and Figure 3).

\subsection{SEASONALITY OF NEE AND GEP RELATED TO VEGETATION PROPERTIES}

We found close interactions between the timing of management and changes in the direction and magnitude of atmospheric exchange fluxes (GEP, NEE and $R_{\text {eco }}$ ) at all three

10 elevations; but timing and frequency of management differed between the study sites. Here we followed two different approaches in order to compare the three sites. First, we compared the magnitude of the different vegetation properties without immediate use of the site-specific temporal scale. Those vegetation properties include vegetation height, plant area and above-ground biomass. Second, we compared vegetation properties against

15 GEP, which can be seen as a flux representation of the integral of time and climatic drivers. In addition, we divided the growing season in three management periods, before the first cut (I), periods thereafter (II) and grazing periods (III).

The classification of management periods helped identify particular effects of management. The pronounced weekly increments in AGB during the first vegetation

20 period matched the increments in the sum of NEE at all three sites (Figure 4), albeit that significant $\mathrm{C}$ uptake (daily GEP > daily $\mathrm{R}_{\mathrm{eco}}$ ) appeared to precede the above-ground vegetation mass increase in spring. This suggested that vegetation was active $1-2$ weeks prior to major above-ground changes, or in other words, showed photosynthetic uptake of between 30 and $50 \mathrm{~g} \mathrm{C} \mathrm{m}^{-2}$ without substantial above-ground biomass increase. A 
similar correlation between AGB and NEE was not apparent during the later regrowth periods. At all three sites net $\mathrm{CO}_{2}$ emissions were observed immediately after each cut for a duration of approximately $1-3$ weeks (Figure 4; shown as a negative slope for time against $-\sum$ NEE). These emissions can be attributed, in part, to organic fertilizer 5 application following harvest, but also to low photosynthetic rates and high maintenance respiration required by plants to re-establish the canopy after a cut. In some instances, the harvest was followed by a notable decrease in AGB. In absence of grazing, the AGB decrease was assumed to be caused by the die-back of damaged shoots that were being replaced by new shoots (as observed in the field).

10 The relationships between the cumulative GEP and $h_{c}$, PAI and AGB appeared similar at all the study sites. Typically the cumulative GEP continued to increase whereas AGB and PAI values reached a plateau at on average $120 \mathrm{gC} \mathrm{m}^{-2}$ and $4.2 \mathrm{~m}^{2} \mathrm{~m}^{-2}$, respectively (Figure 5, which includes GEP data preceding the onset of the vegetation period). The vegetation height was an exception, because it continued to increase with cumulative GEP

15 (Figure 5a). In the period up to the first harvest, $h_{c}$ reached a higher maximum at similar cumulative GEP values. During later management periods (period class II), the generalized relationship between cumulative GEP and $h_{c}$ showed a linear relationship. Tall growing species, such as greater burnet-saxifrage (Pimpinella major), which can obtain more light higher in the canopy, could have dominated GEP, while shorter, but

20 more abundant species, become increasingly shaded and may die off. As would be expected, we did not find a similar relationship between vegetation changes and GEP during the period when grazing took place at the Graswang study site.

The daily height observations, $h_{c-a}$, were only moderately represented by the empirical model based on weekly field surveys, $h_{c-m}$ (Figure 6 and Figure 5) and a clear 
relationship with daily productivity rates could not be determined (Figure $6 \mathrm{~g}-\mathrm{i}$ ). However, sudden height increases coincided with the appearance of herbaceous flowering species at the lower elevations and tall flowering grasses at the highest elevation (Figure 2; see section 3.2 and Appendix C). To further validate the applicability of the automated

5 height measurements, we compared the spring season $h_{c-a}$ of other years on record (Figure 7). Compared to 2015, the observed spring seasons between 2012 and 2016 showed significant variability in spring canopy development. The variability was shown in the timing and rate of height change as well as the maximum vegetation height reached at the time of harvest. The latter was shown particularly clearly at the Rottenbuch site,

10 where a very strict harvest schedule was maintained between the years. The timing of the onset of canopy growth (height minimum) in spring was not the dominant predictor of the vegetation height during harvest (maximum), as was notably indicated during 2012 and 2014 by a late and early spring, respectively, at all study sites (Figure 7). At the highest elevation site, the timing of flowering was marked by sharp height increases,

15 found to be related to tall flowering species (Figure 7a; after day 140).

\subsection{CARBON USE EFFICIENCY}

The relative contribution of GEP to NEE or changes in AGB can be evaluated from their relationship expressed as carbon use efficiency (CUE). Most weekly intervals showed similar magnitudes of AGB increase and C uptake, which was expressed as CUE values

20 between 0 and $100 \%$, defined as $\left\{-\sum\right.$ NEE $/-\sum$ GEP $\}$ or $\left\{\Delta\right.$ AGB $/-\sum$ GEP $\}$ (Figure 8 , but see also Figure 4). However, there were notable exceptions. First, AGB increments exceeded the GEP as soon as the vegetation showed height change, being most pronounced between 8-15 May at Graswang (Figure 8a). Second, a number of intervals showed low or no significant change in AGB while atmospheric uptake was maintained, 
such as between 15 - 21 May at Graswang (Figure 8a), 9 - 16 July at Graswang (Figure $8 \mathrm{~b}$ ), and $18-25$ June at Fendt (Figure $8 \mathrm{f}$ ). Third, the net release of $\mathrm{C}$ to the atmosphere was shown to coincide with a decrease in AGB, such as between $15-21$ May at Rottenbuch and Fendt (Figure 8d and Figure 8f).

5 In addition to the AGB estimates, the daily vegetation height data was used with the previously established model to estimate daily $\mathrm{AGB}_{\text {mod }}$ increments (Figure 8). These modelled daily AGB results partly matched the patterns found in the AGB and NEE based CUE outcomes described above. More importantly, periods of moderate CUE $(>50 \%)$ based on weekly AGB increments appeared to precede the periods of high CUE based on

10 the derived daily $\mathrm{AGB}_{\text {mod }}$ values.

\section{Discussion}

\subsection{Productivity: SEASONALITY AND SPATIAL GRADIENTS}

The annual gross and net productivity of the sites in this study were in line with previous reports for managed temperate grasslands in Europe, especially those at similar elevations

15 in proximity of the Alps (Jones and Donnelly, 2004; Rogiers et al., 2005; Ammann et al., 2007; Cernusca et al., 2008; Hiller et al., 2008; Wohlfahrt et al., 2008; Schmitt et al., 2010; Peichl et al., 2010; Zeeman et al., 2010, 2017). Without exception, these studies underpin the impact of management on the annual $\mathrm{C}$ cycle of temperate grassland ecosystems, besides variability in local environmental drivers. A second common aspect

20 is evidence for a significant role of the spring regrowth period in the annual $\mathrm{C}$ balance. Interestingly, Peichl et al. (2013) suggested that moderately stable rates of daily NEE found within the first regrowth period of the season could be more than a site-specific trait, and be evidence for convergence among contrasting C3 grasslands, within the 
constraints of seasonality, environmental variability and management. The results in this study confirmed that spring growth periods represents high rates of uptake (NEE, GEP) and canopy dynamics (mass increase, height increase, leaf area increase; see also Wingler and Hennessy, 2016), but also indicated that the spring growing periods (see Table 2)

5 under typical management can be shorter than the 30-days window suggested by Peichl et al. (2013) for the determination of the potential NEE rates.

Determining a trend between the sites in this study along the implied elevational gradient may lead to oversimplification. Although some factors followed the elevation differences, such as temperature, productivity and season length, other factors clearly do not support 10 it, including species abundance, species properties and distribution of plant functional types. The higher productivity at the Fendt site followed the higher temperatures and, in particular, a less persistent snow cover, compared to the other sites (Zeeman et al., 2017). This allowed an earlier onset of the growing season and thus contributed to a $96 \%$ higher yield for the first harvest of the season, compared to the next study site, Rottenbuch.

15 Interestingly, variability in environmental conditions following weather anomalies also affected management timing and yield differently at each of the sites. For example, the second harvest at Fendt was delayed until soil conditions improved to a point where heavy machine access to the field was again possible, which made the period up to the second harvest at Fendt at least a week longer than in previous years (Table 2 and Appendix A).

20 In addition to radiation, temperature and $\mathrm{LAI}$, the $\mathrm{C} / \mathrm{N}$ of vegetation may be a determinative factor for productivity, which could help explain differences between the two lower elevation sites (Körner and Diemer, 1987; Musavi et al., 2016). There was an observed gradient in vegetation $\mathrm{C} / \mathrm{N}$ values, which tended to increase from Fendt to Graswang (DE-Fen: 13.3, DE-Rbw: 13.5, DE-Gwg: 13.9). The lower C/N values at Fendt 
could be attributed to a higher abundance of nitrogen fixing clover, which could potentially lead to the observed productivity increase (in AGB and GEP). The ecological indicators (Table 2) used to derive species-related environmental drivers did not fully explain the observed spatial patterns, but rather pointed to differences in the management

5 regimes across the sites.

\subsection{VEGETATION STRUCTURE DYNAMICS}

Current Dynamic Global Vegetation Models describe plant biophysical and biogeochemical relationships in terms of leaf area (Oleson et al., 2013; Mahowald et al., 2016). However, model assumptions about vegetation structure development in response

10 to growth and atmospheric exchange signify a sensitivity that must be thoroughly validated, particularly for highly dynamic vegetation such as managed humid temperate grasslands (Novick et al., 2004; Fatichi et al., 2014a, 2014b; Jones et al., 2017; Klein et al., 2018; Sándor et al., 2018). Furthermore, the classical methods for field observation of vegetation structure, through destructive sampling and canopy light transmissivity

15 surveys, showed substantial potential for systematic error, and serves as a cautionary lesson. Differences in sampling protocol and instrumentation may explain why observations of PAI in different years at the same study site showed a very different range of values (Asam et al., 2013; PAI up to 8 for DE-Fen). If mechanistic models at the ecosystem level are to explain the variability in vegetation properties and $\mathrm{C}$ sequestration

20 as shown in this study, then reliable daily observations of canopy structure are an indispensable pre-requisite. Such observations can be derived using contact-less groundbased remote sensing (e.g., $h_{c-a}$ ) and surveys (e.g., $\mathrm{PAI}_{\mathrm{eff}}$ and $h_{c-m}$ ) that in turn are linked to airborne and satellite data at larger resolutions and scales (Buschmann and Nagel, 1993; Friedl et al., 1994; Zhu et al., 2013; Asam et al., 2013). Contactless sensing 
may provide valuable information about the leaf area and height. But it is unclear if new scanning methods designed to assess canopy gap fraction for sufficiently large areas can be reliably applied to such dense, short-statured vegetation (Danson et al., 2014). In addition, the weekly relationships between height and biomass and height and leaf area

5 presented here, showed that studying vegetation dynamics and phenological development in detail would require frequent (daily) surveys with fine-scale $(\mathrm{cm})$ resolution, particularly if trends are to be resolved (Cleland et al., 2007). Such satellite/airborne data are, to our knowledge, not yet available.

The daily vegetation height data observed here, included information about height 10 distributions (Figure 3). Differences in height distribution may be the result of the acoustic reflections at surfaces at various heights in the canopy, each contributing to sample variance. We assume that this signal was enhanced at Graswang by the lower intensity management, allowing time for the canopy and flowers to mature (see Appendix C). At all elevations the intervals of fast and slow (or negative) increments in height were 15 correlated to productivity (AGB and GEP), assumedly linked to a co-varying PAI. A fully developed grassland canopy reaches a development plateau at which height and leaf area are maintained to achieve optimum GEP rates given the limitations of structural support and competition, e.g. for light. However, the results suggest that the observed height changes may not be directly linked to changes in the rate of biomass increase, but that

20 such patterns can instead help identify major structural changes of the canopy. Vegetation height information may help the interpretation of other contact-less plant phenological observations, including color indices derived from time-lapsed digital camera still images at the site level and high-resolution imagery from airborne surveys near the surface (Migliavacca et al., 2011; Wingate et al., 2015; Vrieling et al., 2018; Brenner et al., 2018), 
particular when variability in the onset and duration of winter pose a vulnerability for vegetation activity (Zeeman et al., 2017; Richardson et al., 2018). Finally, the daily information about the vegetation height may help improve eddy covariance estimates of the surface exchange. The effect of using a daily maximum ( $\mathrm{P}\{97.5 \%\}$ quantile) or 5 minimum ( $\mathrm{P}\{2.5 \%\}$ quantile) height to replace the vegetation height in computations of turbulence statistics was however less than $0.5 \%$ for the sites in this study. This can be explained by the large relative separation between EC observations $(>2.3 \mathrm{~m})$ and the vegetation $(<1 \mathrm{~m})$, which assumedly extends above the roughness sublayer most of the time.

10 The patterns of weekly CUE highlighted the relationship between surface fluxes and biomass increase, as well as caveats when using vegetation height information to infer productivity. The daily photosynthetically assimilated C (i.e., GEP $>0$, gross uptake) must be assumed to be partly respired back to the atmosphere (i.e., $R_{\text {eco }}$ ) and the difference between the two component fluxes (i.e., NEE $<0$, net uptake) is allocated

15 between above- and below-ground growth compartements. However, the sign and magnitude of NEE increments may well differ from the AGB increments, implying a decoupling of growth and atmospheric uptake of $\mathrm{C}$ under the influence of management practices. A CUE $>100 \%$ implied that $\mathrm{C}$ uptake during these intervals was allocated to below-ground storage or, hypothetically, a major transition in above-ground composition

20 took place with limited net mass change. A CUE $<0 \%$ implied that AGB increases were not only driven by atmospheric uptake during that time and must relate to reallocation from below-ground resources. Field observation in the days after harvest showed that residual vegetation (stubs and damaged leaves) were replaced by newly grown leaves, suggesting that the leaf area, a primary controlling factor of GEP, at first declined before 
regrowth was initiated, driven by below-ground resources. The vegetation height could not be shown to provide comparable CUE information, suggesting that the relationship between $h_{c-m}$ and the AGB did not consistently capture the daily dynamics, and fast changes towards the end of each of the managed regrowth periods were more likely

5 correlated with the development of tall flowering organs than the development of leaves. Interestingly, some of the signal appeared time-lagged by several days compared to the AGB increase (Figure 8a), suggesting growth may follow initially sequestered carbon.

Detailed vegetation structure observations together with atmospheric exchange observations likely offer a relevant contribution to the improvement of mechanistic

10 ecosystem model simulations of managed grasslands, particularly where the full energy, water and nutrient balances of the system, including ex situ pools, are included (Soussana et al., 2007a; Keenan et al., 2011; Gelfand and Robertson, 2015; Jones et al., 2017).

\section{CONCLUSIONS}

The three grassland sites in this study revealed a pattern of similarity in biophysical and

15 biogeochemical seasonality, despite differences in species composition, management and elevation. Vegetation state changes showed common patterns along the elevation gradient when expressed as function of (cumulative) gross ecosystem productivity instead of time. This was obvious despite differences in species composition and functional group abundances between the study sites at different elevations. In addition to measurements

20 of plant area and biomass, contact-less continuous observation of canopy height was shown useful for the interpretation of the grasslands' seasonality in terms of vegetation dynamics and atmospheric $\mathrm{CO}_{2}$ exchange. However, in order to use such high-resolution height measurements as a proxy for $\mathrm{CO}_{2}$ exchange process, the observations should be made with a larger spatial representation. The continuous observations of vegetation 
height, as applied here, may find use in the estimation of aerodynamic resistance of the grassland canopy and the improvement of the EC measurements where vegetation height details are used in computation, such as in the estimation of atmospheric stability. Information about height changes may prove valuable for the evaluation of mechanistic

5 models linked to remote sensing products that determine surface height among other vegetation state changes, with a sensitivity and return time that matches the changes seen in managed temperate grasslands. Further, vegetation height information may help the interpretation of other contact-less plant-phenological observations, including vegetation indices derived from time-lapsed digital camera images.

\section{$10 \quad 6 \quad$ ACKNOWLEDGEMENTS}

We thank Martina Bauerfeind (KIT/IMK-IFU) for assistance in the lab and thank our local partners at the observatory sites for their support. This study built upon TERENO/ScaleX cooperation and we thank Benjamin Wolf (KIT/IMK-IFU) and the Scientific Team of ScaleX Campaign 2015 for their contribution. The TERrestrial

15 Environmental Observatory (TERENO) infrastructure is funded by the Helmholtz Association and the Federal Ministry of Education and Research. MJZ and NKR received support from the German Research Foundation (DFG; project ZE 1006/2-1 and RU 1657/2-1). The German Meteorological Service (DWD) is thanked for collecting climate data and making these available through the WebWerdis data warehouse. The map was

20 produced using Copernicus data and information bases funded by the European Union EU-DEM layers. 


\section{BIBLIOGRAPHY}

Ammann, C., Flechard, C.R., Leifeld, J., Neftel, A., Fuhrer, J., 2007. The carbon budget of newly established temperate grassland depends on management intensity. Agric Ecosyst Env. 121, 5-20.

Asam, S., Fabritius, H., Klein, D., Conrad, C., Dech, S., 2013. Derivation of leaf area index for grassland within alpine upland using multi-temporal RapidEye data. Int. J. Remote Sens. 34, 8628-8652. https://doi.org/10.1080/01431161.2013.845316

Aubinet, M., Vesala, T., Papale, D. (Eds.), 2012. Eddy Covariance: A Practical Guide to Measurement and Data Analysis. Springer. https://doi.org/10.1007/978-94-0072351-1

Baldocchi, D., 2008. 'Breathing' of the terrestrial biosphere: lessons learned from a global network of carbon dioxide flux measurement systems. Aust J Bot 56, 1-26. https://doi.org/10.1071/BT07151

15 Bartelheimer, M., Poschlod, P., 2016. Functional characterizations of Ellenberg indicator values - a review on ecophysiological determinants. Funct. Ecol. 30, 506-516. https://doi.org/10.1111/1365-2435.12531

Brenner, C., Zeeman, M., Bernhardt, M., Schulz, K., 2018. Estimation of evapotranspiration of temperate grassland based on high-resolution thermal and visible range imagery from unmanned aerial systems. Int. J. Remote Sens. 1-34. https://doi.org/10.1080/01431161.2018.1471550

Briemle, G., Nitsche, S., Nitsche, L., 2002. BIOLFLOR - Eine Datenbank mit biologischökologischen Merkmalen zur Flora von Deutschland, in: Klotz, S., Kühn, I., Durka, W. (Eds.), Schriftenreihe Für Vegetationskunde. Bundesamt für Naturschutz, Bonn, pp. 203-225.

Buschmann, C., Nagel, E., 1993. In vivo spectroscopy and internal optics of leaves as basis for remote sensing of vegetation. Int. J. Remote Sens. 14, 711-722. https://doi.org/10.1080/01431169308904370

Cernusca, A., Bahn, M., Berninger, F., Tappeiner, U., Wohlfahrt, G., 2008. Effects of Land-Use Changes on Sources, Sinks and Fluxes of Carbon in European Mountain Grasslands. Ecosystems 11, 1335-1337. https://doi.org/10.1007/s10021-008-9202-8 
Chang, J., Ciais, P., Viovy, N., Vuichard, N., Sultan, B., Soussana, J.-F., 2015. The greenhouse gas balance of European grasslands. Glob. Change Biol. 21, 37483761. https://doi.org/10.1111/gcb.12998

Cleland, E., Chuine, I., Menzel, A., Mooney, H., Schwartz, M., 2007. Shifting plant phenology in response to global change. Trends Ecol. Evol. 22, 357-365. https://doi.org/10.1016/j.tree.2007.04.003

Danson, F.M., Gaulton, R., Armitage, R.P., Disney, M., Gunawan, O., Lewis, P., Pearson, G., Ramirez, A.F., 2014. Developing a dual-wavelength full-waveform terrestrial laser scanner to characterize forest canopy structure. Agric. For. Meteorol. 198199, 7-14. https://doi.org/10.1016/j.agrformet.2014.07.007

Diekmann, M., 2003. Species indicator values as an important tool in applied plant ecology - a review. Basic Appl. Ecol. 4, 493-506. https://doi.org/10.1078/14391791-00185

Ellenberg, H., Weber, H.E., Düll, R., Wirth, V., Werner, W., Paulißen, D., 1992. Zeigerwerte der Pflanzen in Mitteleuropa, 3rd ed, Scripta Geobotanica. Gotze.

Evans, J.R., Poorter, H., 2001. Photosynthetic acclimation of plants to growth irradiance: the relative importance of specific leaf area and nitrogen partitioning in maximizing carbon gain. Plant Cell Environ. 24, 755-767. https://doi.org/10.1046/j.1365-3040.2001.00724.x

20 Falge, E., Baldocchi, D., Olson, R., Anthoni, P., Aubinet, M., Bernhofer, C., Burba, G., Ceulemans, R., Clement, R., Dolman, H., Granier, A., Gross, P., Grunwald, T., Hollinger, D., Jensen, N.O., Katul, G., Keronen, P., Kowalski, A., Lai, C.T., Law, B.E., Meyers, T., Moncrieff, J., Moors, E., Munger, J.W., Pilegaard, K., Rannik, U., Rebmann, C., Suyker, A., Tenhunen, J., Tu, K., Verma, S., Vesala, T., Wilson, K., Wofsy, S., 2001. Gap filling strategies for defensible annual sums of net ecosystem exchange. Agric Meteorol 107, 43-69. https://doi.org/10.1016/S01681923(00)00225-2

Fang, H., Li, W., Wei, S., Jiang, C., 2014. Seasonal variation of leaf area index (LAI) over paddy rice fields in NE China: Intercomparison of destructive sampling, LAI-2200, digital hemispherical photography (DHP), and AccuPAR methods. Agric. For. $\quad$ Meteorol. 198-199, 126-141. https://doi.org/10.1016/j.agrformet.2014.08.005 
Fatichi, S., Leuzinger, S., Körner, C., 2014a. Moving beyond photosynthesis: from carbon source to sink-driven vegetation modeling. New Phytol. 201, 1086-1095. https://doi.org/10.1111/nph.12614

Fatichi, S., Zeeman, M.J., Fuhrer, J., Burlando, P., 2014b. Ecohydrological effects of management on subalpine grasslands: From local to catchment scale. Water Resour. Res. 50, 148-164. https://doi.org/10.1002/2013wr014535

Flanagan, L.B., Wever, L.A., Carlson, P.J., 2002. Seasonal and interannual variation in carbon dioxide exchange and carbon balance in a northern temperate grassland. Glob. Change Biol 8, 599-615. https://doi.org/10.1046/j.13652486.2002.00491.x

Friedl, M.A., Schimel, D.S., Michaelsen, J., Davis, F.W., Walker, H., 1994. Estimating grassland biomass and leaf area index using ground and satellite data. Int. J. Remote Sens. 15, 1401-1420. https://doi.org/10.1080/01431169408954174

Gelfand, I., Robertson, G.P., 2015. The Ecology of Agricultural Landscapes: Long-Term Research on the Path to Sustainability, in: Hamilton, S.K., Doll, J.E., Robertson, G.P. (Eds.), . Oxford University Press, New York, New York, USA, pp. 310-339.

Gilgen, A.K., Buchmann, N., 2009. Response of temperate grasslands at different altitudes to simulated summer drought differed but scaled with annual precipitation. Biogeosciences 6, 2525-2539. https://doi.org/10.5194/bg-6-25252009

Gilmanov, T.G., Soussana, J.E., Aires, L., Allard, V., Ammann, C., Balzarolo, M., Barcza, Z., Bernhofer, C., Campbell, C.L., Cernusca, A., Cescatti, A., CliftonBrown, J., Dirks, B.O.M., Dore, S., Eugster, W., Fuhrer, J., Gimeno, C., Gruenwald, T., Haszpra, L., Hensen, A., Ibrom, A., Jacobs, A.F.G., Jones, M.B., Lanigan, G., Laurila, T., Lohila, A., Manca, G., Marcolla, B., Nagy, Z., Pilegaard, K., Pinter, K., Pio, C., Raschi, A., Rogiers, N., Sanz, M.J., Stefani, P., Sutton, M., Tuba, Z., Valentini, R., Williams, M.L., Wohlfahrt, G., 2007. Partitioning European grassland net ecosystem $\mathrm{CO}_{2}$ exchange into gross primary productivity and ecosystem respiration using light response function analysis. Agric Ecosyst Env. 121, 93-120.

Hiller, R., Zeeman, M., Eugster, W., 2008. Eddy-covariance flux measurements in the complex terrain of an Alpine valley in Switzerland. Bound.-Layer Meteorol 127, 449-467. 
Janssens, I.A., Freibauer, A., Ciais, P., Smith, P., Nabuurs, G.J., Folberth, G., Schlamadinger, B., Hutjes, R.W.A., Ceulemans, R., Schulze, E.D., Valentini, R., Dolman, A.J., 2003. Europe's terrestrial biosphere absorbs 7 to $12 \%$ of European anthropogenic $\mathrm{CO}_{2}$ emissions. Science 300, 1538-1542.

5 Jones, J.W., Antle, J.M., Basso, B., Boote, K.J., Conant, R.T., Foster, I., Godfray, H.C.J., Herrero, M., Howitt, R.E., Janssen, S., Keating, B.A., Munoz-Carpena, R., Porter, C.H., Rosenzweig, C., Wheeler, T.R., 2017. Brief history of agricultural systems modeling. Agric. Syst. 155, 240-254. https://doi.org/10.1016/j.agsy.2016.05.014

Jones, M.B., Donnelly, A., 2004. Carbon sequestration in temperate grassland ecosystems and the influence of management, climate and elevated $\mathrm{CO}_{2}$. New Phytol. 164, 423-439. https://doi.org/10.1111/j.1469-8137.2004.01201.x

Jones, S.K., Helfter, C., Anderson, M., Coyle, M., Campbell, C., Famulari, D., Di Marco, C., van Dijk, N., Tang, Y.S., Topp, C.F.E., Kiese, R., Kindler, R., Siemens, J., Schrumpf, M., Kaiser, K., Nemitz, E., Levy, P.E., Rees, R.M., Sutton, M.A., Skiba, U.M., 2017. The nitrogen, carbon and greenhouse gas budget of a grazed, cut and fertilised temperate grassland. Biogeosciences 14, 2069-2088. https://doi.org/10.5194/bg-14-2069-2017

Jørgensen, C.J., Struwe, S., Elberling, B., 2011. Temporal trends in $\mathrm{N}_{2} \mathrm{O}$ flux dynamics in a Danish wetland - effects of plant-mediated gas transport of $\mathrm{N}_{2} \mathrm{O}$ and $\mathrm{O}_{2}$ following changes in water level and soil mineral-N availability. Glob. Change Biol. 18, 210-222. https://doi.org/10.1111/j.1365-2486.2011.02485.x

Keenan, T.F., Grote, R., Sabaté, S., 2011. Overlooking the canopy: The importance of canopy structure in scaling isoprenoid emissions from the leaf to the landscape. Ecol. Model. 222, 737-747. https://doi.org/10.1016/j.ecolmodel.2010.11.004

25 Kiese, R., Fersch, B., Baessler, C., Brosy, C., Butterbach-Bahl, K., Chwala, C., Dannenmann, M., Fu, J., Gasche, R., Grote, R., Jahn, C., Klatt, J., Kunstmann, H., Mauder, M., Rödiger, T., Smiatek, G., Soltani, M., Steinbrecher, R., Völksch I., Werhahn, J., Wolf, B., Zeeman, M., Schmid, H.P., 2018. The TERENOpreAlpine Observatory integrating meteorological, hydrological and biogeochemical measurements and modelling. Vadose Zone J. https://doi.org/10.2136/vzj2018.03.0060

Klein, C., Biernath, C., Heinlein, F., Thieme, C., Gilgen, A.K., Zeeman, M., Priesack, E., 2018. Vegetation Growth Models Improve Surface Layer Flux Simulations of a 
Temperate Grassland. Vadose Zone $\quad$ J. 16 . https://doi.org/10.2136/vzj2017.03.0052

Körner, C., Diemer, M., 1987. In situ Photosynthetic Responses to Light, Temperature and Carbon Dioxide in Herbaceous Plants from Low and High Altitude. Funct. Ecol. 1, 179-194.

Lichtenthaler, H.K., Buschmann, C., Döll, M., Fietz, H.-J., Bach, T., Kozel, U., Meier, D., Rahmsdorf, U., 1981. Photosynthetic activity, chloroplast ultrastructure, and leaf characteristics of high-light and low-light plants and of sun and shade leaves. Photosynth. Res. 2, 115-141. https://doi.org/10.1007/bf00028752

10 Lloyd, J., Taylor, J.A., 1994. On The Temperature-Dependence Of Soil Respiration. Funct. Ecol. 8, 315-323.

Mahowald, N., Lo, F., Zheng, Y., Harrison, L., Funk, C., Lombardozzi, D., Goodale, C., 2016. Projections of leaf area index in earth system models. Earth Syst. Dyn. 7, 211-229. https://doi.org/10.5194/esd-7-211-2016

15 Mauder, M., Cuntz, M., Drüe, C., Graf, A., Rebmann, C., Schmid, H.P., Schmidt, M., Steinbrecher, R., 2013. A strategy for quality and uncertainty assessment of longterm eddy-covariance measurements. Agric. For. Meteorol. 169, 122-135. https://doi.org/10.1016/j.agrformet.2012.09.006

Migliavacca, M., Galvagno, M., Cremonese, E., Rossini, M., Meroni, M., Sonnentag, O., Cogliati, S., Manca, G., Diotri, F., Busetto, L., Cescatti, A., Colombo, R., Fava, F., Cella, U.M. di, Pari, E., Siniscalco, C., Richardson, A.D., 2011. Using digital repeat photography and eddy covariance data to model grassland phenology and photosynthetic $\mathrm{CO}_{2}$ uptake. Agric. For. Meteorol. 151, 1325-1337. https://doi.org/10.1016/j.agrformet.2011.05.012

25 Musavi, T., Migliavacca, M., Weg, M.J. van de, Kattge, J., Wohlfahrt, G., Bodegom, P.M. van, Reichstein, M., Bahn, M., Carrara, A., Domingues, T.F., Gavazzi, M., Gianelle, D., Gimeno, C., Granier, A., Gruening, C., Havránková, K., Herbst, M., Hrynkiw, C., Kalhori, A., Kaminski, T., Klumpp, K., Kolari, P., Longdoz, B., Minerbi, S., Montagnani, L., Moors, E., Oechel, W.C., Reich, P.B., Rohatyn, S., Rossi, A., Rotenberg, E., Varlagin, A., Wilkinson, M., Wirth, C., Mahecha, M.D., 2016. Potential and limitations of inferring ecosystem photosynthetic capacity from leaf functional traits. Ecol. Evol. 6, 7352-7366. https://doi.org/10.1002/ece3.2479 
Novick, K.A., Stoy, P.C., Katul, G.G., Ellsworth, D.S., Siqueira, M.B.S., Juang, J., Oren, R., 2004. Carbon dioxide and water vapor exchange in a warm temperate grassland. Oecologia 138, 259-274. https://doi.org/10.1007/s00442-003-1388-z

Oleson, K., Lawrence, D., Bonan, G., Drewniak, B., Huang, M., Koven, C., Levis, S., Li, F., Riley, W., Subin, Z., Swenson, S., Thornton, P., Bozbiyik, A., Fisher, R., Heald, C., Kluzek, E., Lamarque, J.-F., Lawrence, P., Leung, L., Lipscomb, W., Muszala, S., Ricciuto, D., Sacks, W., Sun, Y., Tang, J., Yang, Z.-L., 2013. Technical description of version 4.5 of the Community Land Model (CLM). https://doi.org/10.5065/d6rr1w7m

10 Peichl, M., Leahy, P., Kiely, G., 2010. Six-year Stable Annual Uptake of Carbon Dioxide in Intensively Managed Humid Temperate Grassland. Ecosystems 14, 112-126. https://doi.org/10.1007/s10021-010-9398-2

Peichl, M., Sonnentag, O., Wohlfahrt, G., Flanagan, L.B., Baldocchi, D.D., Kiely, G., Galvagno, M., Gianelle, D., Marcolla, B., Pio, C., Migliavacca, M., Jones, M.B., Saunders, M., 2013. Convergence of potential net ecosystem production among contrasting C3 grasslands. Ecol Let 16, 502-512. https://doi.org/10.1111/ele.12075

R Development Core Team, 2018. R: A Language and Environment for Statistical Computing. R Foundation for Statistical Computing, Vienna, Austria.

20 Richardson, A.D., Hufkens, K., Milliman, T., Aubrecht, D.M., Furze, M.E., Seyednasrollah, B., Krassovski, M.B., Latimer, J.M., Nettles, W.R., Heiderman, R.R., Warren, J.M., Hanson, P.J., 2018. Ecosystem warming extends vegetation activity but heightens vulnerability to cold temperatures. Nature. https://doi.org/10.1038/s41586-018-0399-1

25 Rogiers, N., Eugster, W., Furger, M., Siegwolf, R., 2005. Effect of land management on ecosystem carbon fluxes at a subalpine grassland site in the Swiss Alps. Theor Appl Clim. 80, 187-203.

Sándor, R., Ehrhardt, F., Brilli, L., Carozzi, M., Recous, S., Smith, P., Snow, V., Soussana, J.-F., Dorich, C.D., Fuchs, K., Fitton, N., Gongadze, K., Klumpp, K., Liebig, M., Martin, R., Merbold, L., Newton, P.C.D., Rees, R.M., Rolinski, S., Bellocchi, G., 2018. The use of biogeochemical models to evaluate mitigation of greenhouse gas emissions from managed grasslands. Sci. Total Environ. 642, 292-306. https://doi.org/10.1016/j.scitotenv.2018.06.020 
Schmitt, M., Bahn, M., Wohlfahrt, G., Tappeiner, U., Cernusca, A., 2010. Land use affects the net ecosystem $\mathrm{CO}_{2}$ exchange and its components in mountain grasslands. Biogeosciences 7, 2297-2309. https://doi.org/10.5194/bg-7-22972010

5 Schneider, C.A., Rasband, W.S., Eliceiri, K.W., 2012. NIH Image to ImageJ: 25 years of image analysis. Nat. Methods 9, 671-675. https://doi.org/10.1038/nmeth.2089

Scurlock, J.M.O., Johnson, K., Olson, R.J., 2002. Estimating net primary productivity from grassland biomass dynamics measurements. Glob. Change Biol. 8, 736-753. https://doi.org/10.1046/j.1365-2486.2002.00512.x

10 Soussana, J.F., Allard, V., Pilegaard, K., Ambus, P., Amman, C., Campbell, C., Ceschia, E., Clifton-Brown, J., Czobel, S., Domingues, R., Flechard, C., Fuhrer, J., Hensen, A., Horvath, L., Jones, M., Kasper, G., Martin, C., Nagy, Z., Neftel, A., Raschi, A., Baronti, S., Rees, R.M., Skiba, U., Stefani, P., Manca, G., Sutton, M., Tuba, Z., Valentini, R., 2007a. Full accounting of the greenhouse gas $\left(\mathrm{CO}_{2}, \mathrm{~N}_{2} \mathrm{O}, \mathrm{CH}_{4}\right)$ budget of nine European grassland sites. Agric. Ecosyst. Environ. 121, 121-134. https://doi.org/10.1016/j.agee.2006.12.022

Soussana, J.F., Fuhrer, J., Jones, M., Amstel, A.V., 2007b. The greenhouse gas balance of grasslands in Europe. Agric Ecosyst Env. 121, 1-4. https://doi.org/10.1016/j.agee.2006.12.001

20 Vrieling, A., Meroni, M., Darvishzadeh, R., Skidmore, A.K., Wang, T., Zurita-Milla, R., Oosterbeek, K., O’Connor, B., Paganini, M., 2018. Vegetation phenology from Sentinel-2 and field cameras for a Dutch barrier island. Remote Sens. Environ. https://doi.org/10.1016/j.rse.2018.03.014

Wang, C., Chen, Z., Unteregelsbacher, S., Lu, H., Gschwendtner, S., Gasche, R., Kolar, A., Schloter, M., Kiese, R., Butterbach-Bahl, K., Dannenmann, M., 2016. Climate change amplifies gross nitrogen turnover in montane grasslands of Central Europe in both summer and winter seasons. Glob. Change Biol. 22, 2963-2978. https://doi.org/10.1111/gcb.13353

Wingate, L., Ogée, J., Cremonese, E., Filippa, G., Mizunuma, T., Migliavacca, M., Moisy, C., Wilkinson, M., Moureaux, C., Wohlfahrt, G., Hammerle, A., Hörtnagl, L., Gimeno, C., Porcar-Castell, A., Galvagno, M., Nakaji, T., Morison, J., Kolle, O., Knohl, A., Kutsch, W., Kolari, P., Nikinmaa, E., Ibrom, A., Gielen, B., Eugster, W., Balzarolo, M., Papale, D., Klumpp, K., Köstner, B., Grünwald, T., 
Joffre, R., Ourcival, J.-M., Hellstrom, M., Lindroth, A., George, C., Longdoz, B., Genty, B., Levula, J., Heinesch, B., Sprintsin, M., Yakir, D., Manise, T., Guyon, D., Ahrends, H., Plaza-Aguilar, A., Guan, J.H., Grace, J., 2015. Interpreting canopy development and physiology using a European phenology camera network at flux sites. Biogeosciences 12, 5995-6015. https://doi.org/10.5194/bg$12-5995-2015$

Wingler, A., Hennessy, D., 2016. Limitation of Grassland Productivity by Low Temperature and Seasonality of Growth. Front. Plant Sci. 7. https://doi.org/10.3389/fpls.2016.01130

10 Wohlfahrt, G., Hammerle, A., Haslwanter, A., Bahn, M., Tappeiner, U., Cernusca, A., 2008. Seasonal and inter-annual variability of the net ecosystem $\mathrm{CO}_{2}$ exchange of a temperate mountain grassland: Effects of weather and management. J Geophys Res 113. https://doi.org/10.1029/2007JD009286

Wolf, B., Chwala, C., Fersch, B., Garvelmann, J., Junkermann, W., Zeeman, M.J., Angerer, A., Adler, B., Beck, C., Brosy, C., Brugger, P., Emeis, S., Dannenmann, M., Roo, F.D., Diaz-Pines, E., Haas, E., Hagen, M., Hajnsek, I., Jacobeit, J., Jagdhuber, T., Kalthoff, N., Kiese, R., Kunstmann, H., Kosak, O., Krieg, R., Malchow, C., Mauder, M., Merz, R., Notarnicola, C., Philipp, A., Reif, W., Reineke, S., Rödiger, T., Ruehr, N., Schäfer, K., Schrön, M., Senatore, A., Shupe, H., Völksch, I., Wanninger, C., Zacharias, S., Schmid, H.P., 2017. The SCALEX Campaign: Scale-Crossing Land Surface and Boundary Layer Processes in the TERENO-preAlpine Observatory. Bull. Am. Meteorol. Soc. 98, 1217-1234. https://doi.org/10.1175/BAMS-D-15-00277.1

Zacharias, S., Bogena, H., Samaniego, L., Mauder, M., s, R.F., Pütz, T., Frenzel, M., Schwank, M., Baessler, C., Butterbach-Bahl, K., Bens, O., Borg, E., Brauer, A., Dietrich, P., Hajnsek, I., Helle, G., Kiese, R., Kunstmann, H., Klotz, S., Munch, J.C., Papen, H., Priesack, E., Schmid, H.P., Steinbrecher, R., Rosenbaum, U., Teutsch, G., Vereecken, H., 2011. A Network of Terrestrial Environmental Observatories in Germany. Vadose Zone J. 10, 955. https://doi.org/10.2136/vzj2010.0139

Zeeman, M.J., Hiller, R., Gilgen, A.K., Michna, P., Plüss, P., Buchmann, N., Eugster, W., 2010. Management and climate impacts on net $\mathrm{CO}_{2}$ fluxes and carbon budgets of 
three grasslands along an elevational gradient in Switzerland. Agric. For. Meteorol. 150, 519-530. https://doi.org/10.1016/j.agrformet.2010.01.011

Zeeman, M.J., Mauder, M., Steinbrecher, R., Heidbach, K., Eckart, E., Schmid, H.P., 2017. Reduced snow cover affects productivity of upland temperate grasslands. $\begin{array}{llll}\text { Agric. } & \text { For. } & \text { 5eteorol. } & \text { 232, }\end{array}$ https://doi.org/10.1016/j.agrformet.2016.09.002

Zhu, Z., Bi, J., Pan, Y., Ganguly, S., Anav, A., Xu, L., Samanta, A., Piao, S., Nemani, R., Myneni, R., 2013. Global Data Sets of Vegetation Leaf Area Index (LAI)3g and Fraction of Photosynthetically Active Radiation (FPAR)3g Derived from Global Inventory Modeling and Mapping Studies (GIMMS) Normalized Difference Vegetation Index (NDVI3g) for the Period 1981 to 2011. Remote Sens. 5, 927948. https://doi.org/10.3390/rs5020927 
Tables/Figures

Table 1: Ecological indicator values after Ellenberg et al. (1992) and mowing compatibility, feeding value as well as proportion of species of extensive grasslands

5 after (Briemle et al., 2002) are shown as averaged across all species of each study site; $\mathbf{G}=$ Graswang (864 m), R= Rottenbuch (769 m), F = Fendt (595 m). Ellenberg's indicator values provide information about the prevailing environmental conditions based on the occurrence of different plant species at the study sites.

\begin{tabular}{l|l|l|l|l|l|l|l|l|l}
\hline Site & $\begin{array}{l}\text { Light } \\
(\mathbf{L})\end{array}$ & $\begin{array}{l}\text { Temperature } \\
(\mathbf{T})\end{array}$ & $\begin{array}{l}\text { Continentality } \\
(\mathbf{K})\end{array}$ & $\begin{array}{l}\text { Humidity } \\
(\mathbf{F})\end{array}$ & $\begin{array}{l}\text { Soil } \\
\text { Reaction } \\
(\mathbf{R})\end{array}$ & $\begin{array}{l}\text { Nutrients } \\
(\mathbf{N})\end{array}$ & $\begin{array}{l}\text { Mowing } \\
\text { compati } \\
\text { bility }\end{array}$ & $\begin{array}{l}\text { Feeding } \\
\text { value }\end{array}$ & $\begin{array}{l}\text { Proportion } \\
\text { (\%) species } \\
\text { of extensive } \\
\text { grassland }\end{array}$ \\
\hline $\mathrm{G}$ & 6.8 & 5.1 & 3.6 & 5.4 & 6.0 & 5.7 & 6.2 & 4.7 & 51 \\
\hline $\mathrm{R}$ & 7.0 & 5.1 & 3.4 & 5.3 & 6.3 & 6.1 & 7.1 & 5.9 & 22 \\
\hline $\mathrm{F}$ & 7.0 & 4.9 & 3.6 & 5.5 & 5.9 & 5.8 & 6.5 & 5.5 & 48 \\
\hline
\end{tabular}


Table 2: Shown per harvest period are the the duration (days), the start and end dates (day of year; DOY), the sums of the net ecosystem exchange (NEE), the gross ecosystem productivity (GEP), the harvested above-ground biomass ( $A_{G B} B_{\text {cut }}$; for $\mathrm{C}$ and $N)$ and the residual above-ground biomass $\left(A_{G B}\right.$ res $)$ for the three study sites in

5 2015; $G=$ Graswang $(864 \mathrm{~m}), \mathbf{R}=$ Rottenbuch $(769 \mathrm{~m}), \mathrm{F}=$ Fendt $(595 \mathrm{~m})$. Period Classes (I, II and III) are explained in the text.

\begin{tabular}{|c|c|c|c|c|c|c|c|c|c|}
\hline \multirow[b]{2}{*}{$\begin{array}{l}\text { Sit } \\
\mathrm{e}\end{array}$} & \multirow[b]{2}{*}{$\begin{array}{l}\text { Period / } \\
\text { Period } \\
\text { Class }\end{array}$} & \multirow[b]{2}{*}{$\begin{array}{l}\text { Duration } \\
\text { [From, To] } \\
\text { (days, DOY) }\end{array}$} & \multicolumn{5}{|c|}{$\mathrm{Sum} \pm \mathrm{SE}\left(\mathrm{gC} \mathrm{m}^{-2}\right)$} & \multicolumn{2}{|c|}{$\mathrm{Sum} \pm \mathrm{SE}\left(\mathrm{gN} \mathrm{m}^{-2}\right)$} \\
\hline & & & $N E E$ & $G E P$ & $R_{\text {eсо }}$ & $A G B_{\text {cut }}$ & $A G B_{\text {res }}$ & $A G B_{\text {cut }}$ & \\
\hline G & $1 / \mathrm{I}$ & $46[117,163] \dagger$ & $-171 \pm 16$ & $-426 \pm 4$ & $255 \pm 15$ & $99 \pm 16$ & $23 \pm 7$ & & $7 \pm 1$ \\
\hline G & $2 / \mathrm{II}$ & $54[163,217] \dagger$ & $-82 \pm 23$ & $-452 \pm 2$ & $370 \pm 23$ & $63 \pm 16$ & $62 \pm 16$ & & $5 \pm 1$ \\
\hline G & $3 /$ III & $148[217,365]$ & $-53 \pm 20$ & $-497 \pm 4$ & $444 \pm 19$ & & $35 \pm 7$ & & \\
\hline G & $1-3$ & $248[117,365]$ & $-306 \pm 59$ & $-1375 \pm 10$ & $1069 \pm 57$ & $167 \pm 33$ & $119 \pm 30$ & & $12 \pm 2$ \\
\hline G & Year & 365 & $-252 \pm 76$ & $-1496 \pm 13$ & $1233 \pm 70$ & & & & \\
\hline $\mathrm{R}$ & $1 / \mathrm{I}$ & $25[106,131] \dagger$ & $-97 \pm 2$ & $-228 \pm 1$ & $131 \pm 2$ & $50 \pm 17$ & $43 \pm 9$ & & $4 \pm 1$ \\
\hline $\mathrm{R}$ & $2 / \mathrm{II}$ & $37[131,168] \dagger$ & $-40 \pm 5$ & $-272 \pm 1$ & $231 \pm 5$ & $46 \pm 9$ & $23 \pm 7$ & & $3 \pm 1$ \\
\hline $\mathrm{R}$ & $3 / \mathrm{II}$ & $34[168,202] \dagger$ & $-24 \pm 5$ & $-296 \pm 1$ & $272 \pm 5$ & $59 \pm 8$ & $25 \pm 4$ & & $4 \pm 1$ \\
\hline $\mathrm{R}$ & 4 / II & $38[202,240] \dagger$ & $3 \pm 4$ & $-255 \pm 1$ & $257 \pm 4$ & $52 \pm 15$ & $55 \pm 13$ & & $4 \pm 1$ \\
\hline $\mathrm{R}$ & $5 / \mathrm{II}$ & $41[240,281] \dagger$ & $-20 \pm 3$ & $-245 \pm 1$ & $225 \pm 3$ & $27 \pm 7$ & $32 \pm 5$ & & $2 \pm 1$ \\
\hline $\mathrm{R}$ & $6 / \mathrm{II}$ & $84[281,365]$ & $37 \pm 3$ & $-167 \pm 1$ & $204 \pm 2$ & & $20 \pm 6$ & & \\
\hline $\mathrm{R}$ & $1-6$ & $259[106,365]$ & $-143 \pm 22$ & $-1463 \pm 4$ & $1321 \pm 21$ & $233 \pm 55$ & $199 \pm 43$ & & $17 \pm 4$ \\
\hline $\mathrm{R}$ & Year & 365 & $-88 \pm 33$ & $-1664 \pm 9$ & $1576 \pm 25$ & & & & \\
\hline $\mathrm{F}$ & $1 / \mathrm{I}$ & $30[101,131] \dagger$ & $-103 \pm 12$ & $-276 \pm 3$ & $173 \pm 11$ & $98 \pm 11$ & $40 \pm 10$ & & $7 \pm 1$ \\
\hline $\mathrm{F}$ & $2 / \mathrm{II}$ & $50[131,181] \dagger$ & $-83 \pm 23$ & $-418 \pm 4$ & $335 \pm 22$ & $86 \pm 16$ & $38 \pm 8$ & & $6 \pm 1$ \\
\hline $\mathrm{F}$ & $3 / \mathrm{II}$ & $36[181,217] \dagger$ & $-22 \pm 12$ & $-308 \pm 2$ & $286 \pm 12$ & $72 \pm 16$ & $48 \pm 11$ & & $5 \pm 1$ \\
\hline $\mathrm{F}$ & 4 / II & $36[217,253] \dagger$ & $13 \pm 12$ & $-262 \pm 3$ & $275 \pm 11$ & $61 \pm 20$ & $39 \pm 3$ & & $5 \pm 1$ \\
\hline $\mathrm{F}$ & $5 / \mathrm{II}$ & $31[253,284] \dagger$ & $-4 \pm 7$ & $-147 \pm 1$ & $142 \pm 6$ & $34 \pm 7$ & $33 \pm 4$ & & $3 \pm 1$ \\
\hline $\mathrm{F}$ & $6 / \mathrm{II}$ & $81[284,365]$ & $2 \pm 5$ & $-220 \pm 2$ & $222 \pm 4$ & & $37 \pm 7$ & & \\
\hline $\mathrm{F}$ & $1-6$ & $264[101,365]$ & $-198 \pm 70$ & $-1631 \pm 15$ & $1433 \pm 68$ & $350 \pm 71$ & $236 \pm 44$ & & $26 \pm 5$ \\
\hline $\mathrm{F}$ & Year & 365 & $-197 \pm 88$ & $-1859 \pm 20$ & $1662 \pm 77$ & & & & \\
\hline
\end{tabular}

† Period ends with harvest 


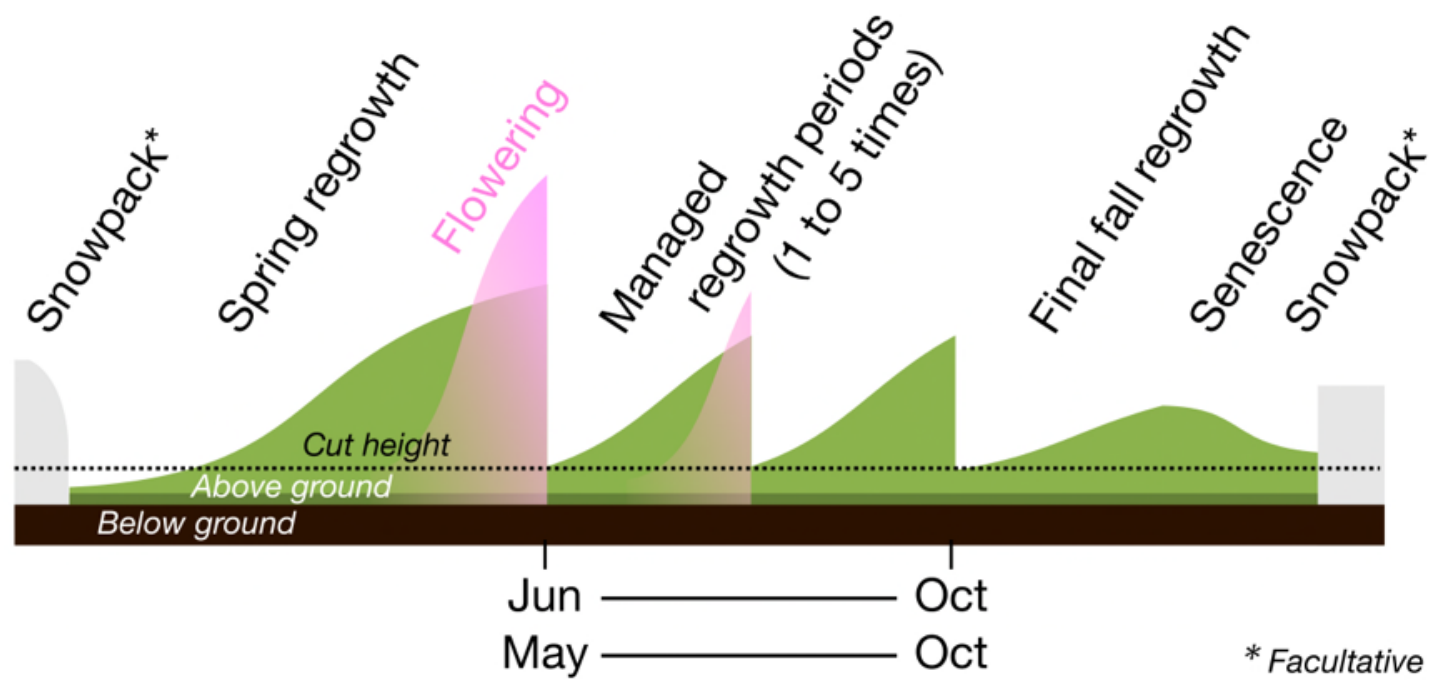

Figure 1: Conceptual framework for seasonal canopy height changes of managed 5 temperate grasslands used for fodder production (meadows) in northern hemisphere. Season length decreases with increasing elevation (from approximately $800 \mathrm{~m}$ above sea level). 


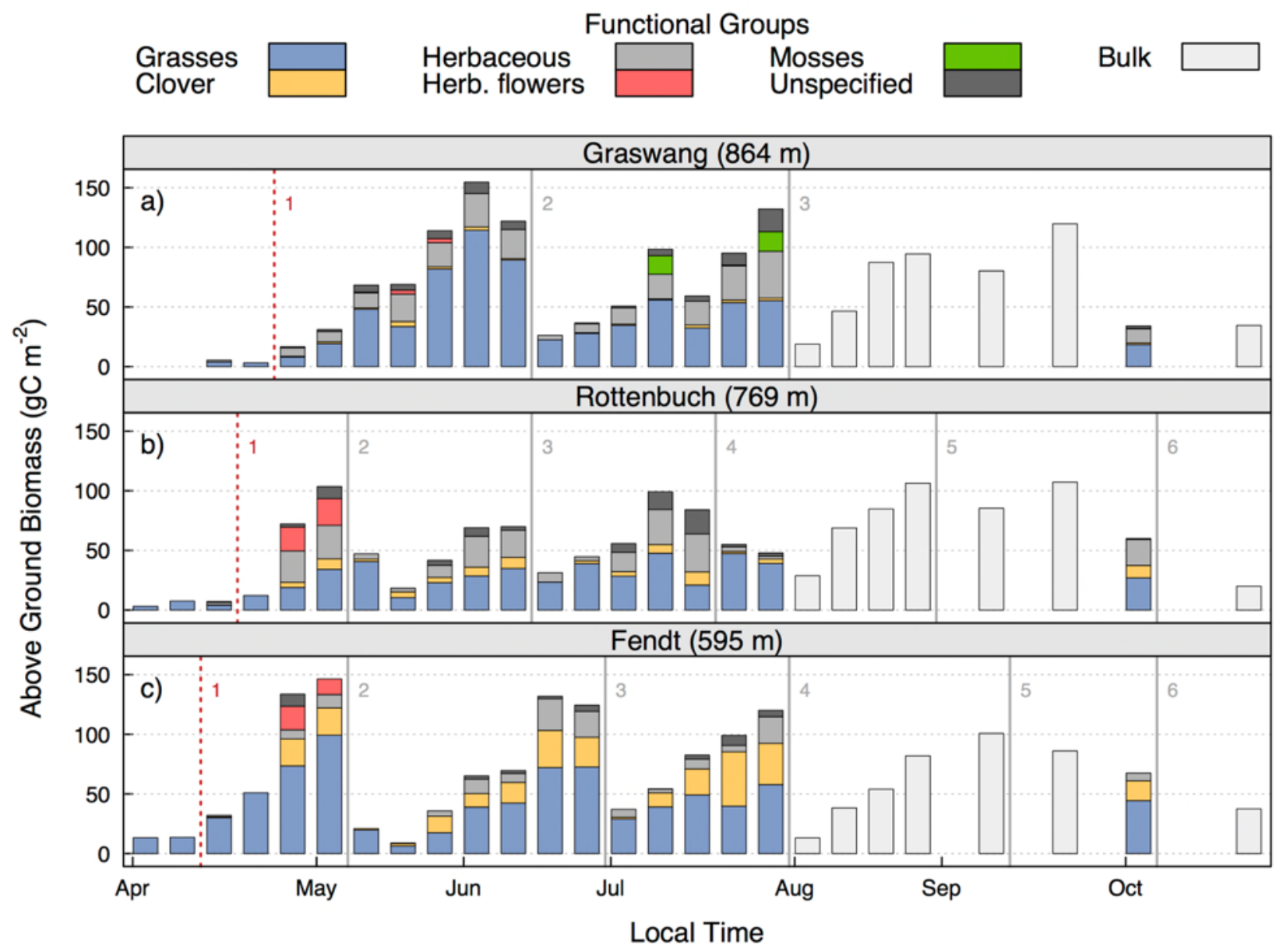

Figure 2: The above ground biomass is specified for functional vegetation groups over time for the three sites a) Graswang b) Rottenbuch and c) Fendt in 2015. Harvest events are indicated by vertical lines. Onset of the growing season is given 5 by the vertical red line. 


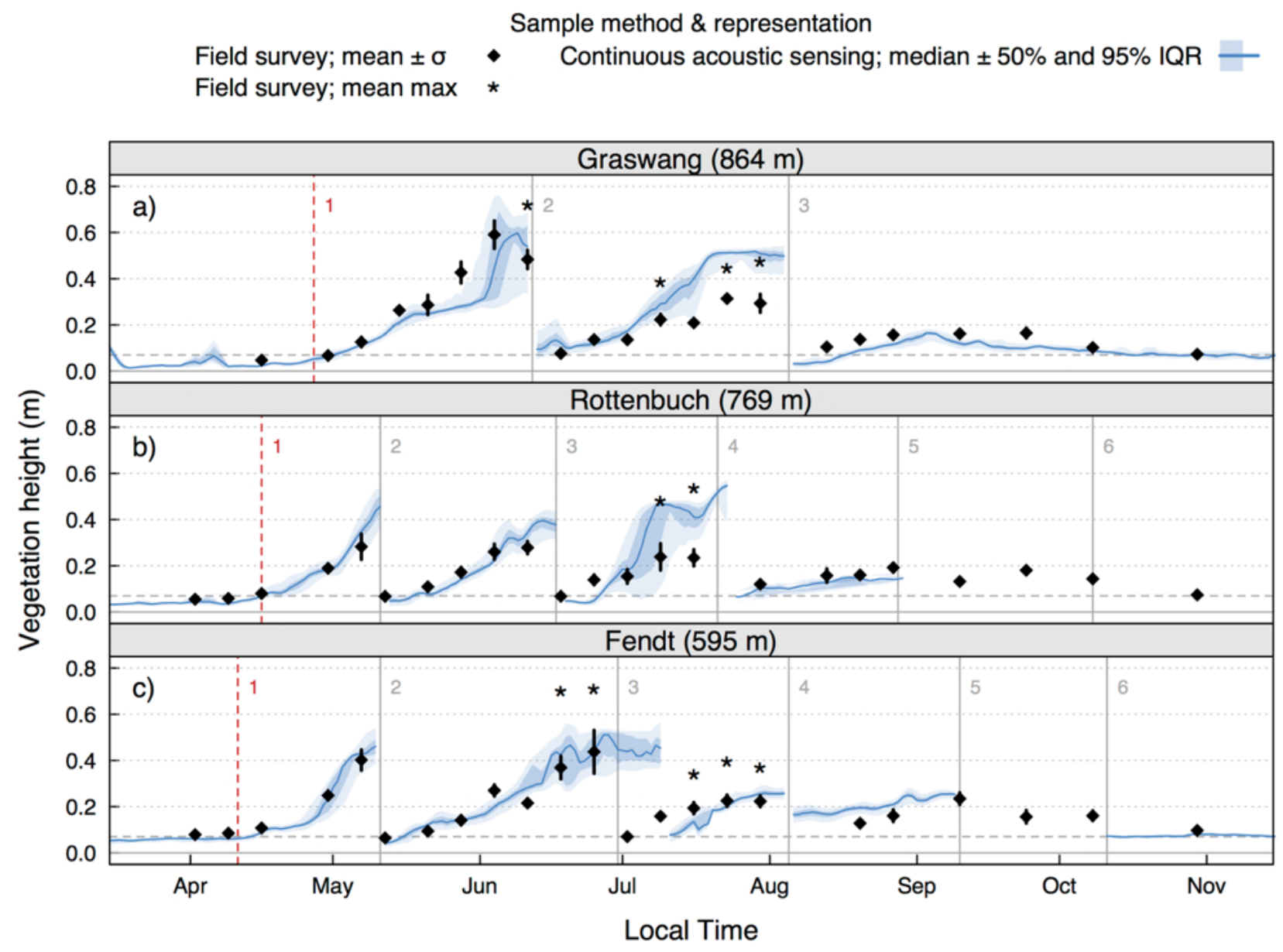

Figure 3: Vegetation height for the three sites a) Graswang b) Rottenbuch and c) Fendt in 2015. Shown are averages from field campaigns and acoustic sensing. Mowing events are highlighted with vertical solid lines and the onset of the 5 vegetation periods in spring are indicated with red dashed lines. The average mowing height of $0.07 \mathrm{~m}$ is given (dashed horizontal line). Data from acoustic sensing are given as median and the interquartile range (IQR). The error bars are \pm 1 SD. 


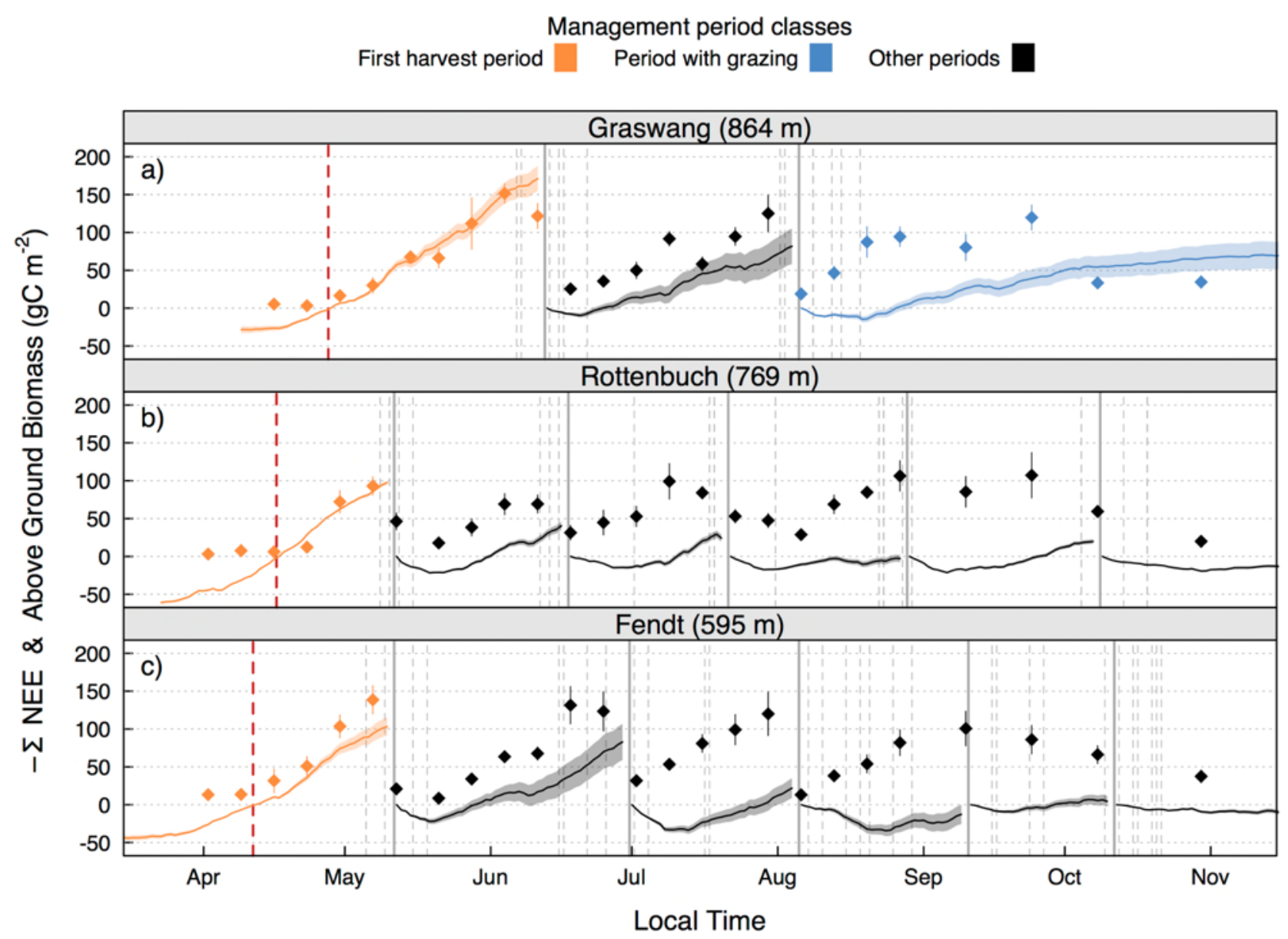

Figure 4: Above-ground biomass (mean $\pm \sigma$ ) and cumulative sum of the net ecosystem exchange ( $\mathrm{NEE} ; \pm \mathrm{CI}$ ) per harvest period in 2015 are given for sites a) Graswang b) Rottenbuch and c) Fendt. The first harvest period (orange) and the 5 period that included grazing (blue) are highlighted as well as the harvest dates during the 2010-2016 period (gray dashed lines). The start of significant increase in vegetation height in spring is shown by vertical red dashes lines. 
Site \& Management period classes

Graswang $(864 \mathrm{~m}) \quad \Delta \quad$ First harvest period (I)

Rottenbuch $(769 \mathrm{~m}) \quad \bullet \quad$ \& Period with grazing (III)

Fendt $(595 \mathrm{~m}) \quad \nabla \quad$ All other periods (II)

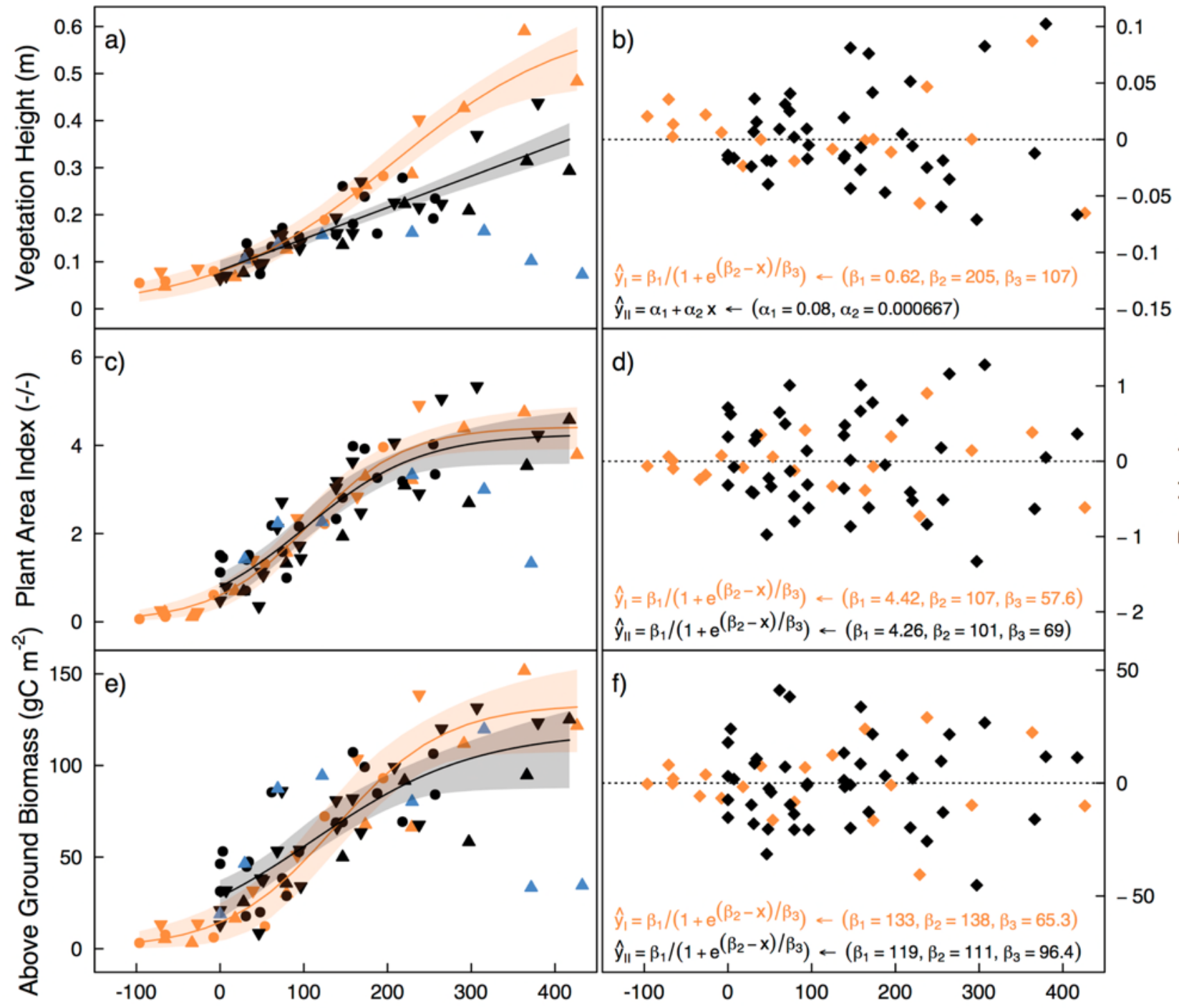

Cumlative sum of Gross Ecosystem Productivity, $-\Sigma$ GEP $\left(\mathrm{gC} \mathrm{m}^{-2}\right)$

Figure 5: The relationship between the cumulative sum of gross ecosystem productivity (GEP) and campaign-averaged vegetation properties are shown. Fit 5 model results for all sites combined and per management period class are given for a) the vegetation height $\left.\left(h_{c-m}\right), c\right)$ the plant area index and e) the above ground biomass. Included are the $\mathbf{9 5 \%} \%$-confidence intervals (transparent area) in the panels on the left and the model residuals and parameters are given in the panels to the right (b,d,f). 


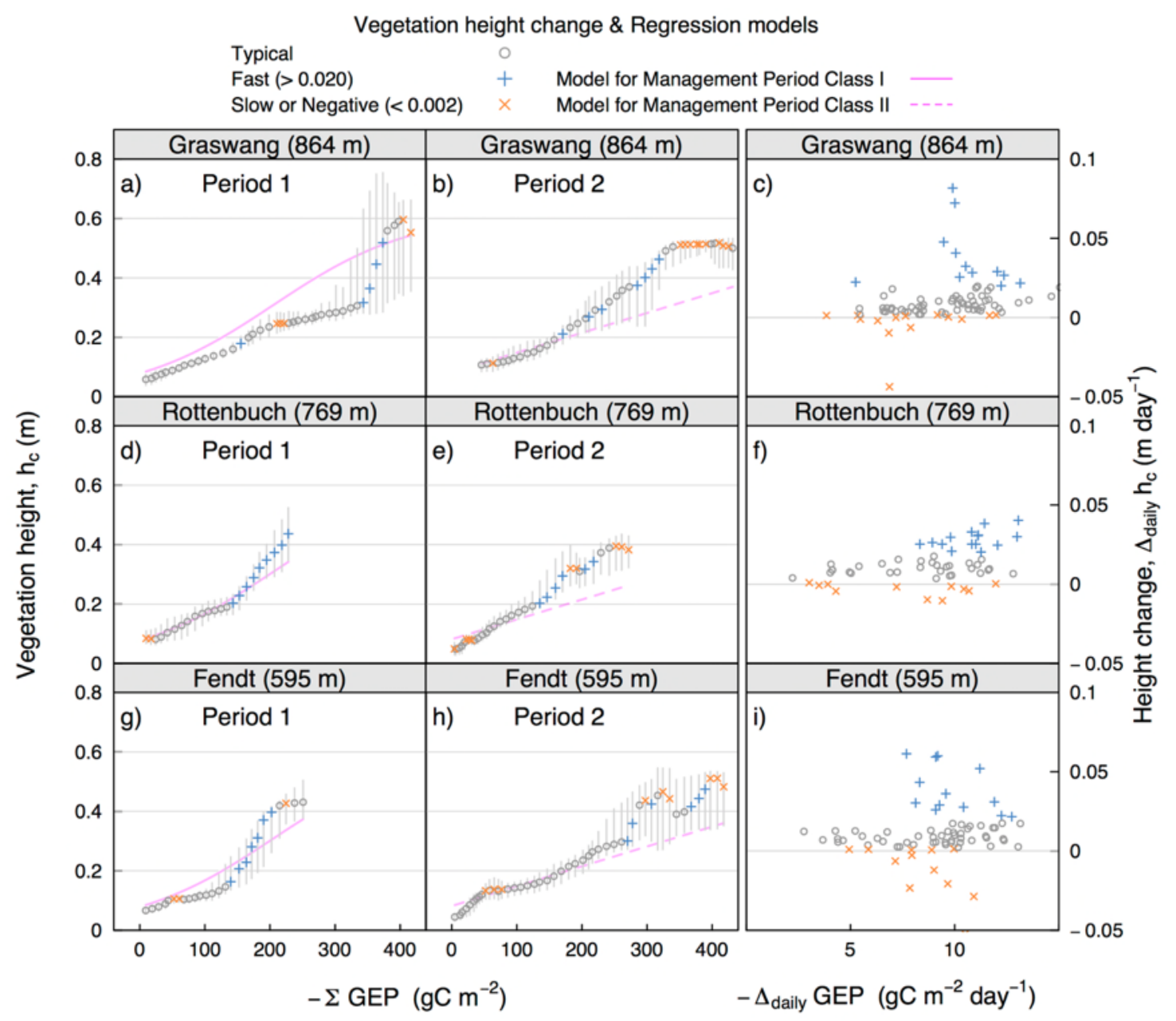

Figure 6: Daily vegetation height $\left(\mathrm{P}\{50 \%\}\right.$ quantile of $\left.\boldsymbol{h}_{c-a}\right)$ is shown against cumulative gross ecosystem productivity (GEP) in a,d,g) in the first harvest periods for Graswang Rottenbuch and Fendt, and in b,e,h) for the second harvest periods; 5 c,f,i) show the rates of daily change corresponding to both periods. The models are shown in Figure 5a - b. Vertical bars indicate the $\mathbf{P}\{2.5 \%\}$ to $\mathbf{P}\{97.5 \%\}$ quantile range and intervals with fast and slow change in height are highlighted, see text for details. 

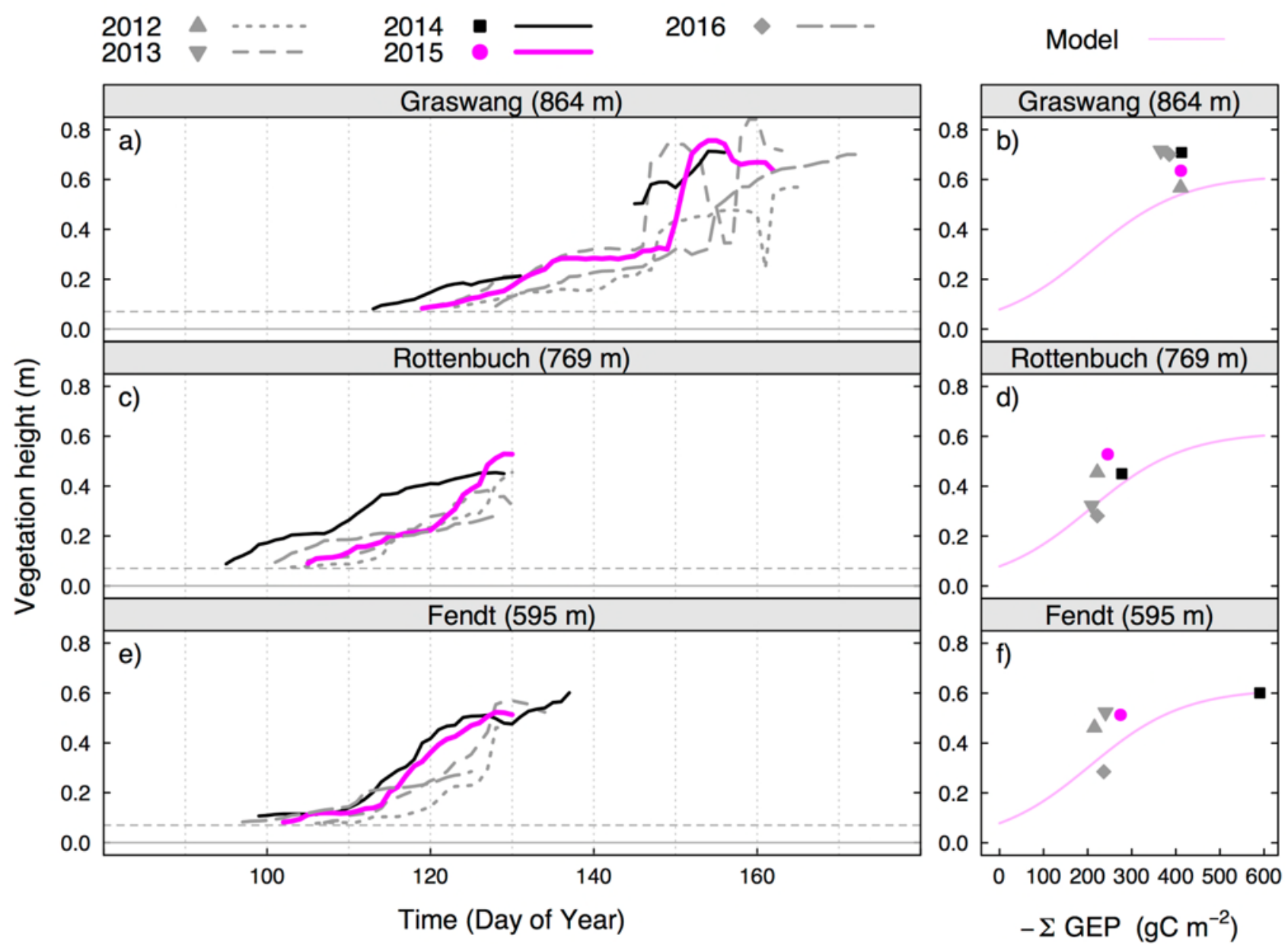

Figure 7: Vegetation height during the first harvest periods between 2012 to 2017 at the three sites a) Graswang, b) Rottenbuch and c) Fendt. The height was estimated from the daily 95th percentile of automated height observations $\left(h_{c-a}\right)$. 


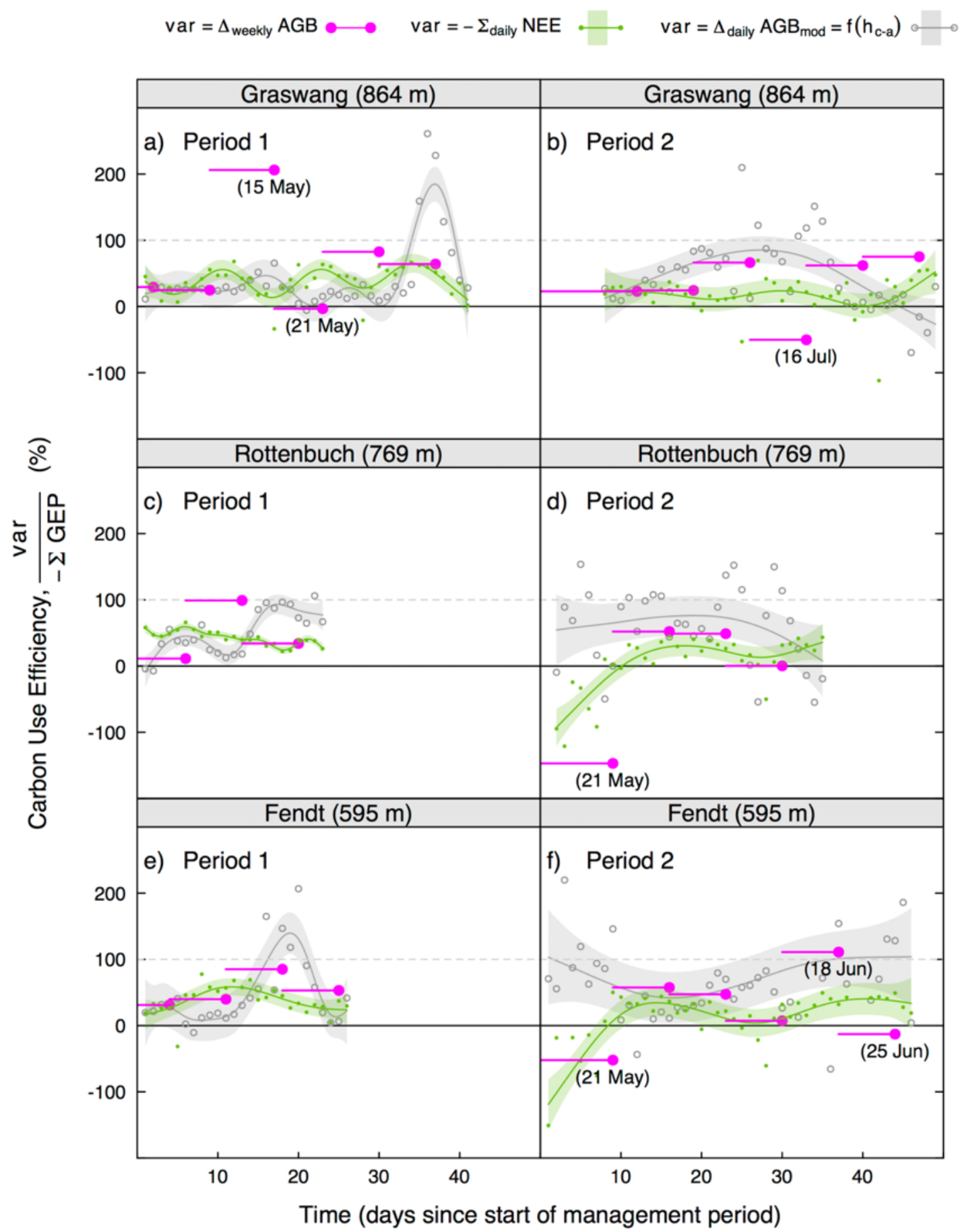

Figure 8: The carbon use efficiency is shown as a fraction of the gross ecosystem productivity (GEP) for the weekly sampled above ground biomass (AGB), the daily sum net ecosystem exchange (NEE) and the daily $A_{\text {GG }}$ mod as derived from a 5 modelled relationship with vegetation height $\left(h_{c-a}\right)$. The periods (1 and 2$)$ refer to the time before the first and second cut. A smoothing function was applied and is shown with confidence interval (lines with envelopes). 


\section{APPENDICES}

\section{Appendix A MAP \& Climatology}

The study sites in the TERENO preAlpine observatory borders the Alps in the South. The sites are approximately $30 \mathrm{~km}$ apart and, together with a different elevation, there is

5 substantial geographic variability between the study sites and in the vicinity of each site (Figure A.9). For the investigation of intra-seasonal vegetation state changes we must review the climatic drivers during the growing season against the long-term records in the area. We reviewed German Weather Service weather station data from two stations near Fendt and assume those to be representative of climatological trends. The months

10 May and June showed more precipitation, whereas July and August were relatively hot and dry in 2015 (Figure A.10 and Figure A.11). The sites showed only a few degrees Kelvin difference in temperature during the growing season, which followed the elevation gradient (Figure A.11). 


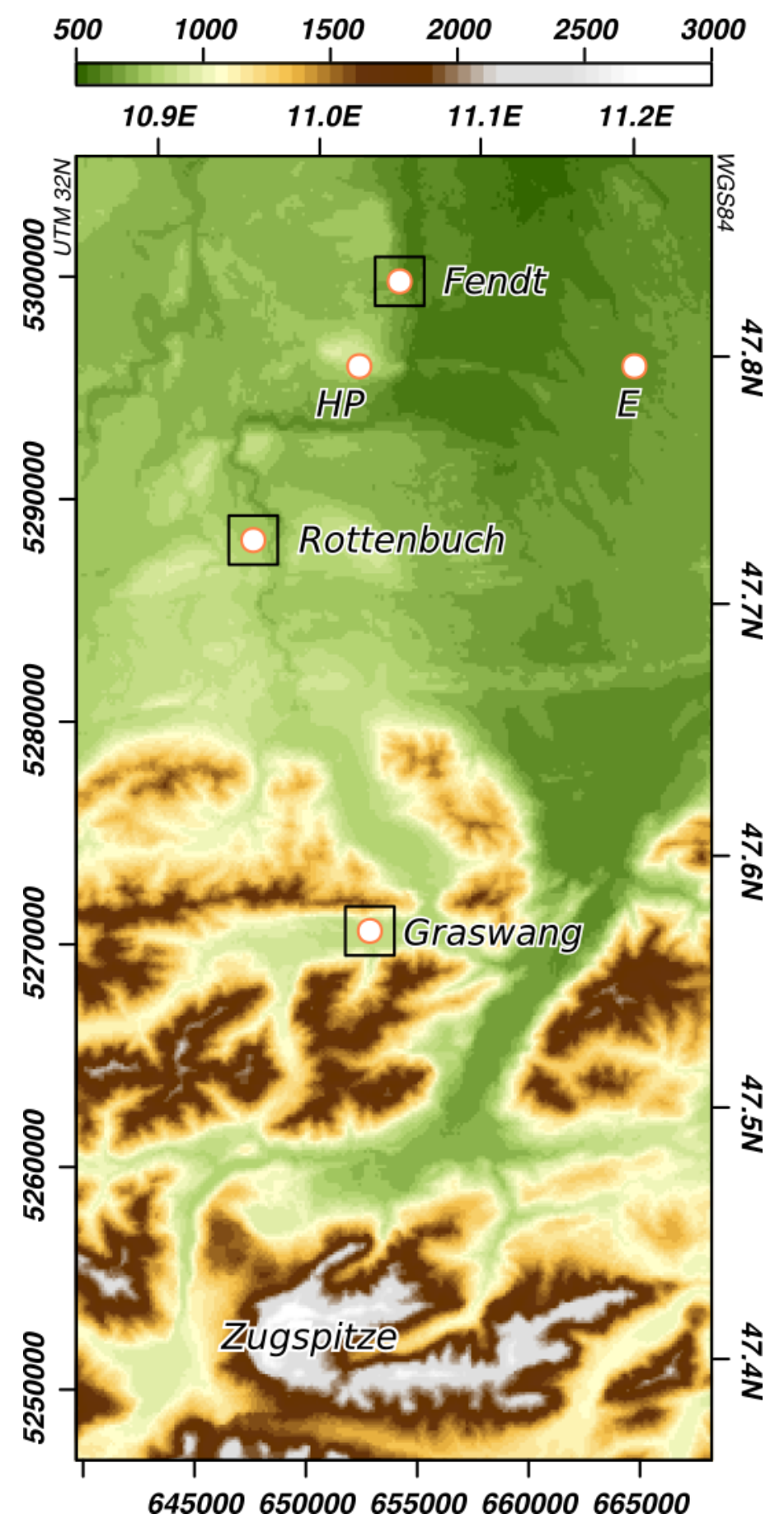

Figure A.9: Topographic map of the study area showing the locations of the study sites Fendt (DE-Fen), Rottenbuch (DE-Rbw) and Graswang (DE-Gwg), as well as the German Weather Service (DWD) operated weather stations Eberfing (E) and 5 Hohenpeißenberg (HP). Modified from (Zeeman, et al. 2017), CC-BY-SA. 


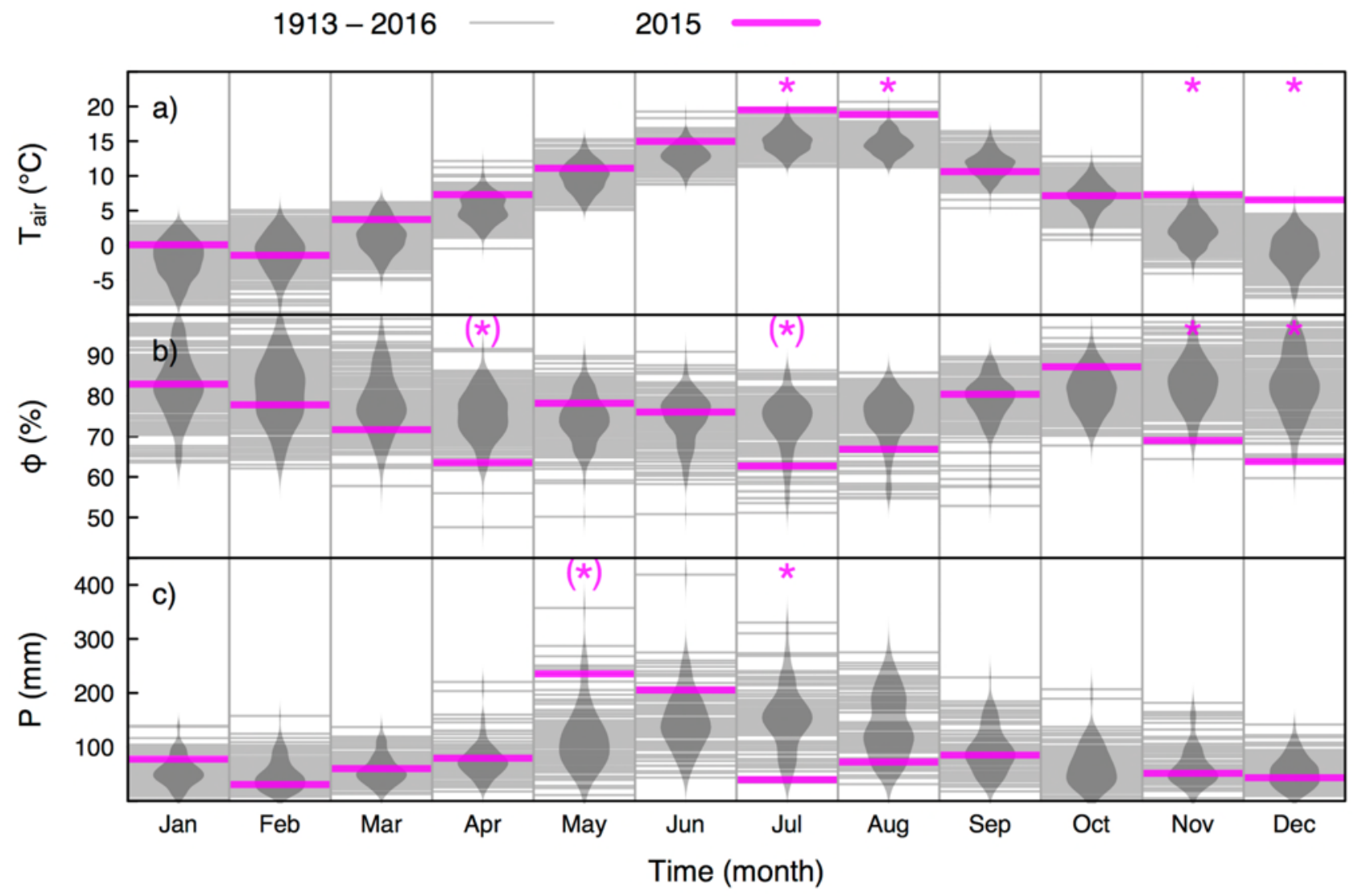

Figure A.10: Monthly a) mean air temperature $\left(T_{\text {air }}\right)$, b) mean relative humidity $(\phi)$ and c) precipitation $(P)$ between 1913 and 2016 at the weather stations Eberfing $\left(T_{\text {air }}\right.$ and $\phi)$ and Hohenpeißenberg ( $P$ only) operated by the German Weather Service 5 (DWD; data available from WebWerdis). The months in 2015 with significant deviation $(p<0.05)$ from the long-term record are highlighted by stars. 


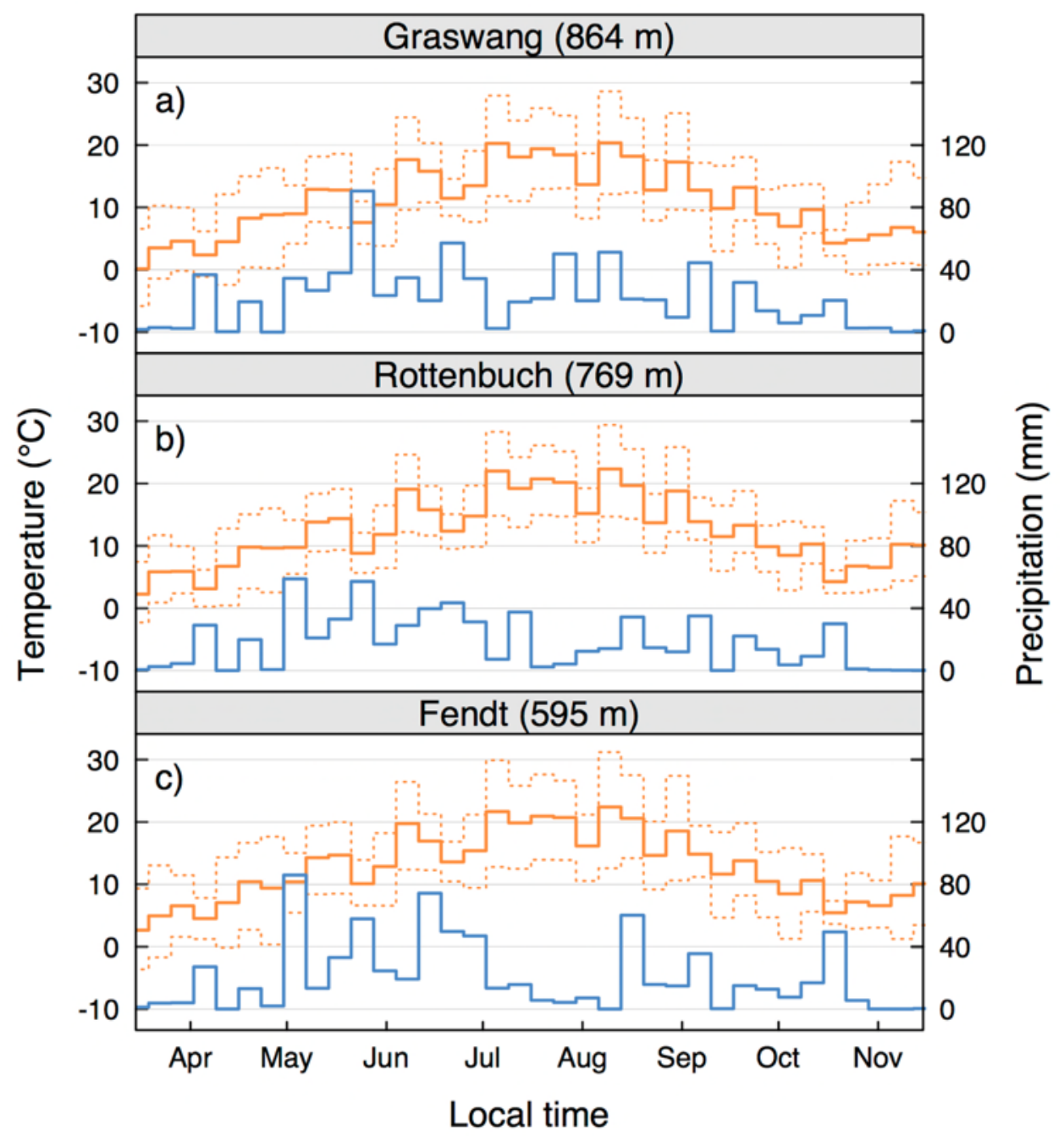

Figure A.11: The mean air temperature and the sum of precipitation during 2015 are shown for the sites a) Graswang, b) Rottenbuch and c) Fendt. 
Appendix B Vegetation Survey

Table B.1: Plant species encountered within $50 \mathrm{~m}$ of the meteorological field stations 5 at Fendt (F; 595 m), Rottenbuch (R; 769 m) and Graswang (G; 864 m) during 2015.

\begin{tabular}{|c|c|c|}
\hline \multirow[t]{2}{*}{ Species } & \multicolumn{2}{|c|}{ Site } \\
\hline & $\mathrm{F}$ & $\mathrm{R} \mathrm{G}$ \\
\hline Alchemilla vulgaris & & - $\bullet$ \\
\hline Alopecurus pratensis & & - $\bullet$ \\
\hline Anthoxanthum odoratum & & - • \\
\hline Bellis perennis & $\bullet$ & $\bullet \bullet$ \\
\hline Carum carvi & $\bullet$ & - • \\
\hline Cerastium holosteoides & $\bullet$ & - $\bullet$ \\
\hline Cynosurus cristatus & & - $\bullet$ \\
\hline Dactylis glomerata & $\bullet$ & - • \\
\hline Festuca rubra & $\bullet$ & - $\bullet$ \\
\hline Heracleum sphondylium & $\bullet$ & $\bullet$ \\
\hline Plantago lanceolata & $\bullet$ & $\bullet$ \\
\hline Plantago major & $\bullet$ & - • \\
\hline Poa pratensis & $\bullet$ & $\bullet$ \\
\hline Rumex obtusifolius & $\bullet$ & - $\bullet$ \\
\hline Taraxacum Sect. Ruderalia & $\bullet$ & $\bullet$ \\
\hline Trifolium pratense & $\bullet$ & $\bullet$ \\
\hline Trisetum flavescens & $\bullet$ & $\bullet$ \\
\hline Veronica chamaedrys & $\bullet$ & $\bullet$ \\
\hline Achillea millefolium & $\bullet$ & $\bullet$ \\
\hline Festuca pratensis & $\bullet$ & $\bullet$ \\
\hline Holcus lanatus & $\bullet$ & $\bullet$ \\
\hline Lathyrus pratensis & $\bullet$ & $\bullet$ \\
\hline Leontodon autumnalis & & $\bullet$ \\
\hline Lolium perenne & $\bullet$ & $\bullet$ \\
\hline Poa trivialis & & $\bullet$ \\
\hline Prunella vulgaris & & $\bullet$ \\
\hline Ranunculus acris & & $\bullet$ \\
\hline Trifolium repens & & $\bullet$ \\
\hline Bistorta officinalis & • & $\bullet$ \\
\hline
\end{tabular}




\begin{tabular}{|c|c|}
\hline Crepis biennis & \\
\hline Galium album & $\bullet$ \\
\hline Lychnis flos-cuculi & $\bullet$ \\
\hline Pimpinella major & $\bullet$ \\
\hline Ranunculus repens & $\bullet$ \\
\hline Rumex acetosa & \\
\hline Agrostis capillaris & $\bullet$ \\
\hline Capsella bursa-pastoris & $\bullet$ \\
\hline Centaurea pseudophrygia & $\bullet$ \\
\hline Cirsium oleracium & $\bullet$ \\
\hline Phleum pratense & $\bullet$ \\
\hline Rumex crispus & $\bullet$ \\
\hline Sanguisorba officinalis & $\bullet$ \\
\hline Stellaria graminea & $\bullet$ \\
\hline Vicia cracca & \\
\hline Vicia sepium & \\
\hline Medicago lupulina & $\bullet$ \\
\hline Veronica arvensis & $\bullet$ \\
\hline Arrhenatherum elatius & \\
\hline Cardamine pratensis & \\
\hline Dactylorhiza maculata & \\
\hline Geum rivale & \\
\hline Glechoma hederacea & \\
\hline Knautia arvensis & \\
\hline Leucanthemum vulgare & \\
\hline Myosotis arvensis & \\
\hline Silene dioica & \\
\hline Taraxacum officinalis & \\
\hline Tragopogon pratensis & \\
\hline Veronica officinalis & \\
\hline Vicia hirsuta & \\
\hline
\end{tabular}




\section{Appendix C Vegetation height, biomass and PAI observations}

\section{C.1 Plant Area Index (PAI)}

The plant area index was determined by non-destructive measurements in the field (LAI5 2200, LiCor, Lincoln, NE, USA) and by destructive biomass sampling followed by measurement in a bench-top leaf area meter (Li-3100C, LiCor, Lincoln, NE, USA). Additionally, we measured specific leaf area from small biomass subsamples and compared results to the LI-3100C measurements and found a $20-25 \%$ underestimation (Figure S11b), which was caused by sample overlap in the leaf area meter and was

10 corrected accordingly. The derived destructive PAI was also compared to the nondestructuve PAI $I_{\text {eff }}$ and showed a linear agreement between methods, where PAI eff were on average about $60 \%$ larger than destructive PAI (Figure S12). We corrected the PAI $\mathrm{Pff}_{\text {f }}$ data accordingly.

The overestimation of $\mathrm{PAI}_{\mathrm{eff}}$ compared to destructive PAI was surprising, as the opposite

15 has been reported in literature (Fang et al., 2014). An explanation could be in the way sampling was performed in the field. We moved the sensor head forward on ground level in order to minimize canopy disturbance above the sensor dome. Therefore, we could not guarantee the manufacturer recommended minimum distance between plant tissue and the sensor head, which could contribute to an overestimation of $\mathrm{PAI}_{\text {eff }}$ observations.

\section{C.2 Vegetation height}

The $h_{c-m}$ and $h_{c-a}$ observations generally agreed well in magnitude and variability at all elevations until July, thereafter the different vegetation height observations showed more deviation, which must be attributed to delays of several days in management just below 
the $h_{c-a}$ sensor, compared to the distributed $h_{c-m}$ samples on the field (Figure C.14). The weekly site visits allowed additional observation of conditions in the field (Figure C.15). At a number of instances the field survey results showed discrepancies with observer estimates of the tallest etalon of the vegetation (Figure 3). The height of the

5 tallest species, particularly at the end of a management period, were not well-represented in the manual vegetation height survey observations. At the highest elevation, vegetation was measured to reach up to approximately $0.7 \mathrm{~m}, 0.4 \mathrm{~m}$ and $0.6 \mathrm{~m}$ on 6 June 2015,16 July 2015 and 30 July 2015, respectively (Figure C.15a, Figure C.15c). The tall species were identified as red fescue (Festuca rubra) and greater burnet-saxifrage (Pimpinella 10 major) in June and July, respectively. Similar observations were made at the middle elevation on 9 July 2015, where hogweed (Heracleum spec.) was present in one sample plot with a height of approximately $0.42 \mathrm{~m}$ (Figure C.15f). Those additional field estimates of the upper height boundary were in line with the upper boundary of the continuous observations of vegetation height at those dates but deviated from the mean

15 (Figure 3). In contrast, the survey observations of height were influenced by the sturdy, tall flower stems of dandelion (Taraxacum spec.), where those were present in moderate abundance in April and May at the lower two sites (see also Figure C.15d). The exclusion of biomass below a height of $0.02 \mathrm{~m}$ was found to be problematic for mosses, which were present in patches at the highest elevation and seemed to dominated the volume closest 20 to the surface (Figure C.15b).

Further, we did not identify an influence of litter on biomass after harvest and where slurry manure had been applied on sample mass (Figure C.15e). Management actions by the farmer typically follow in a rapid succession, where the cut, the pre-harvest desiccation, the preparation for collection, the harvest and subsequent manure application 
usually happens within a few days (Figure C.15e). Therefore, the vegetation sampling protocol requires flexibility to respond on short notice, particularly when a dependency exists on farmer management actions. Although a more frequent sampling could be considered, this can lead to disturbance in the EC observations. Finding relationships to

5 continuous vegetation state observations would deliver pragmatic advantages.

\section{C.3 Relationships between PAI, AGB and $\boldsymbol{h}_{c}$}

Figure D.16 shows the relationship between vegetation height and plant area index of all sites combined. A linear relationship could be established taking the data from all sites and all periods together. However, for vegetation exceeding a height of $0.35 \mathrm{~m}$ asymptotic

10 functions appeared to describe the relationship better (Figure D.16b). This resulted in similar models for vegetation height against PAI with an asymptote for PAI at 5.2 (Figure D.16). The rate constant for the fitted relationship differed between the models for the first management period and subsequent periods without grazing.

We further investigated the correlations between vegetation height, plant area and the

15 above ground biomass (Figure D.17). The first periods showed approximately $55 \%$ taller vegetation per unit biomass than subsequent periods, whereas during the period with grazing the vegetation was again approximately $48 \%$ less tall (Figure D.17b). Further, a relationship could be determined between the above ground biomass and plant area that was similar for all management periods without grazing (Figure D.17c $-\mathrm{d}$ ). In contrast

20 to the vegetation height, grazing had a more profound impact on the correlation between AGB and PAI and no meaningful model fit could be determined. Please note that the presented linear relationships against vegetation height are not expected to be proportional, as for AGB and PAI the lowest $0.02 \mathrm{~m}$ were excluded from the sampling. 


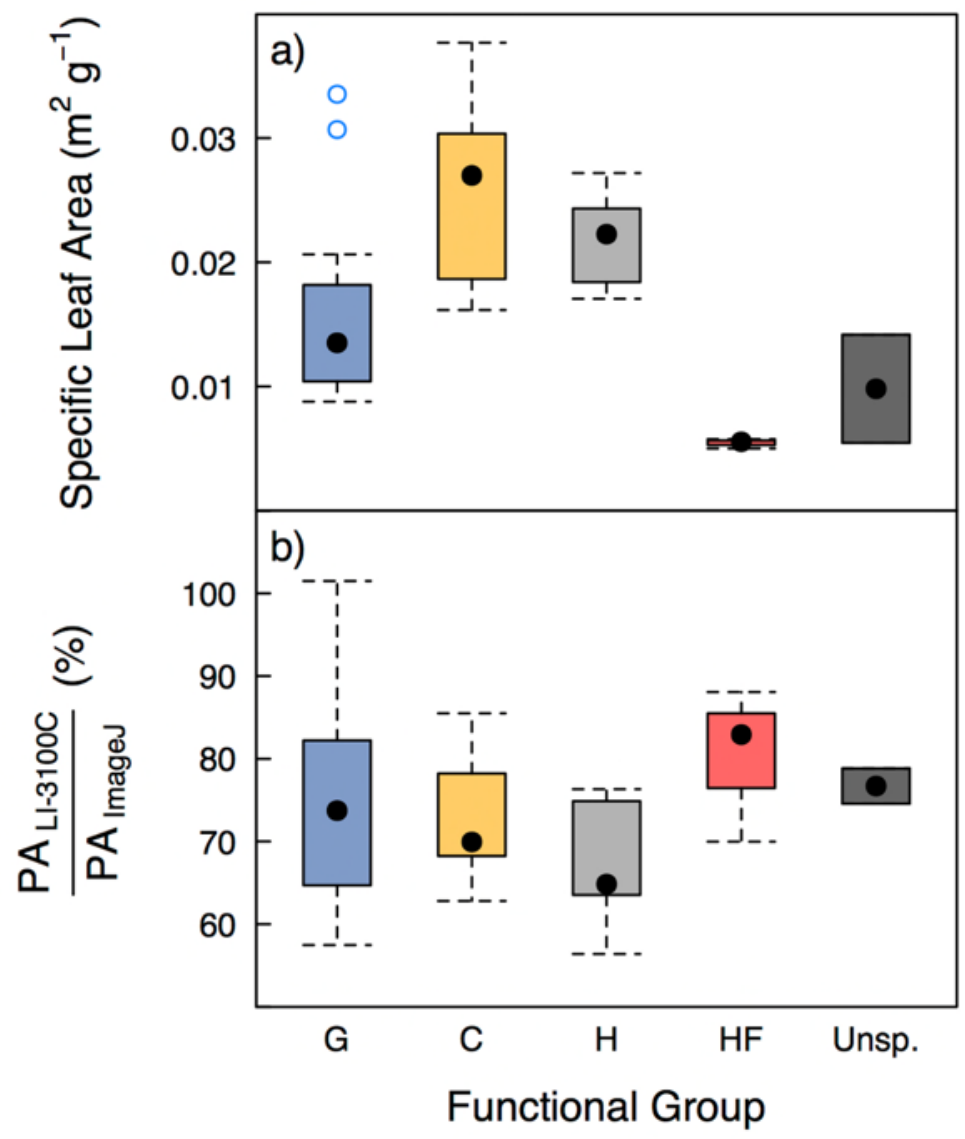

Figure C.12: The a) specific leaf area and b) the relationship between the plant area (PA) determined from camera images (ImageJ) and by leaf area meter (LI-3100C) 5 are shown for different functional groups; $\mathbf{G}=\mathbf{G r a s s e s}, \mathbf{C}=\mathbf{C l o v e r}, \mathbf{H}=$ Herbaceous, HF $=$ Herbaceous Flowers, Unsp. = Unspecified. 


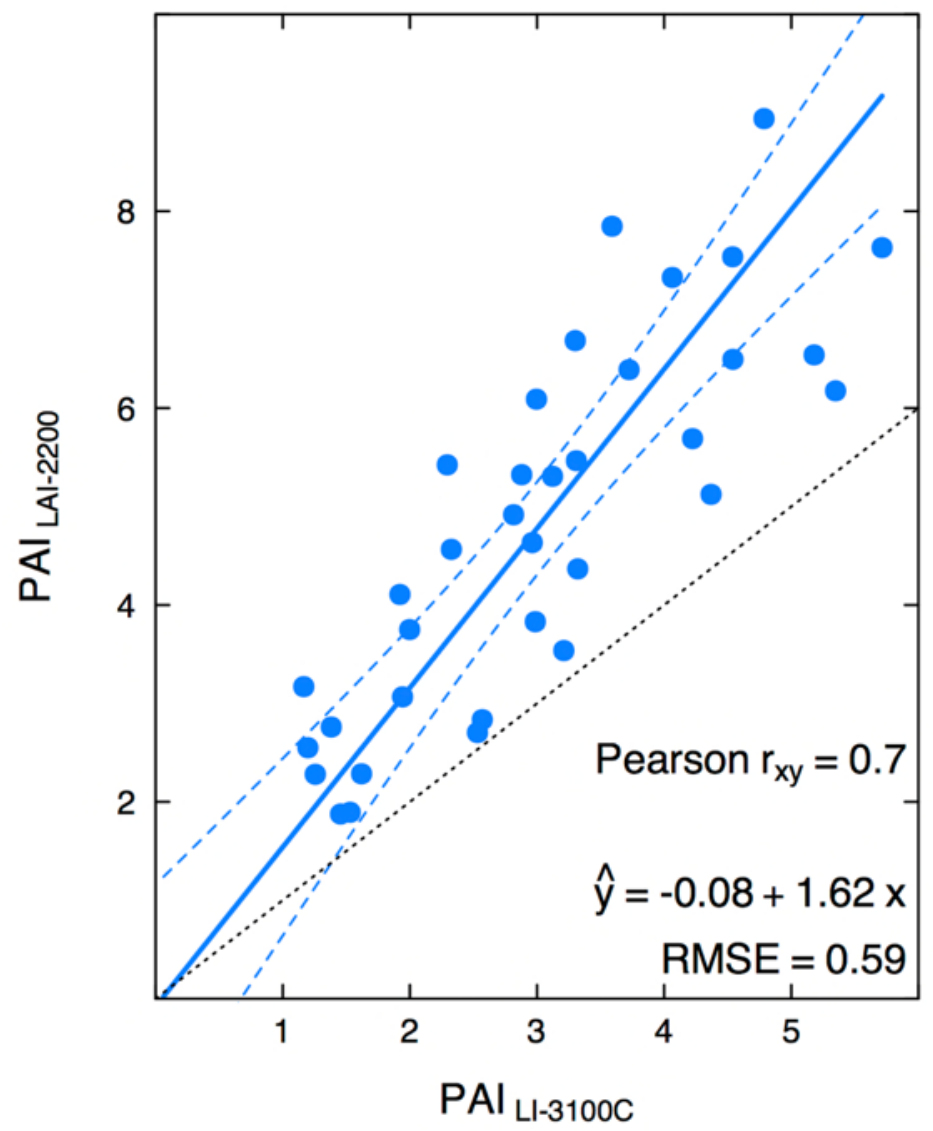

Figure C.13: Relationship between the reference (LI-3100C) and the field survey (LAI-2200) method to determine plant area index (PAI). The identity is shown as dotted line and the blue lines represent the Demming-type regression with 5 confidence interval. $\mathrm{RMSE}=$ root mean square error. 


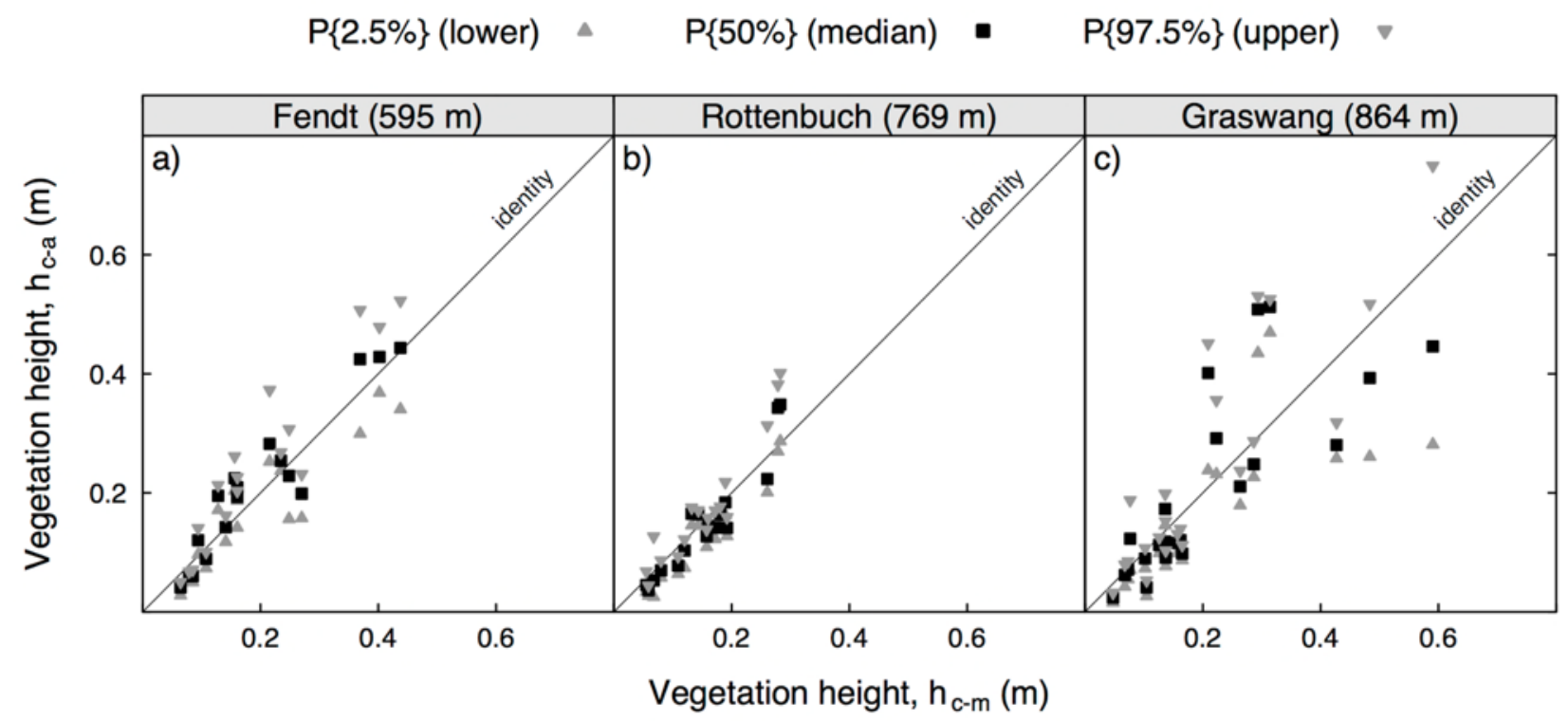

Figure C.14: Relationship between vegetation height as observed by manual surveys $5\left(h_{c-m}\right)$ and acoustic range sensing $\left(h_{c-a}\right)$ during 2015 for the sites a) Fendt, b) Rottenbuch and c) Graswang. 


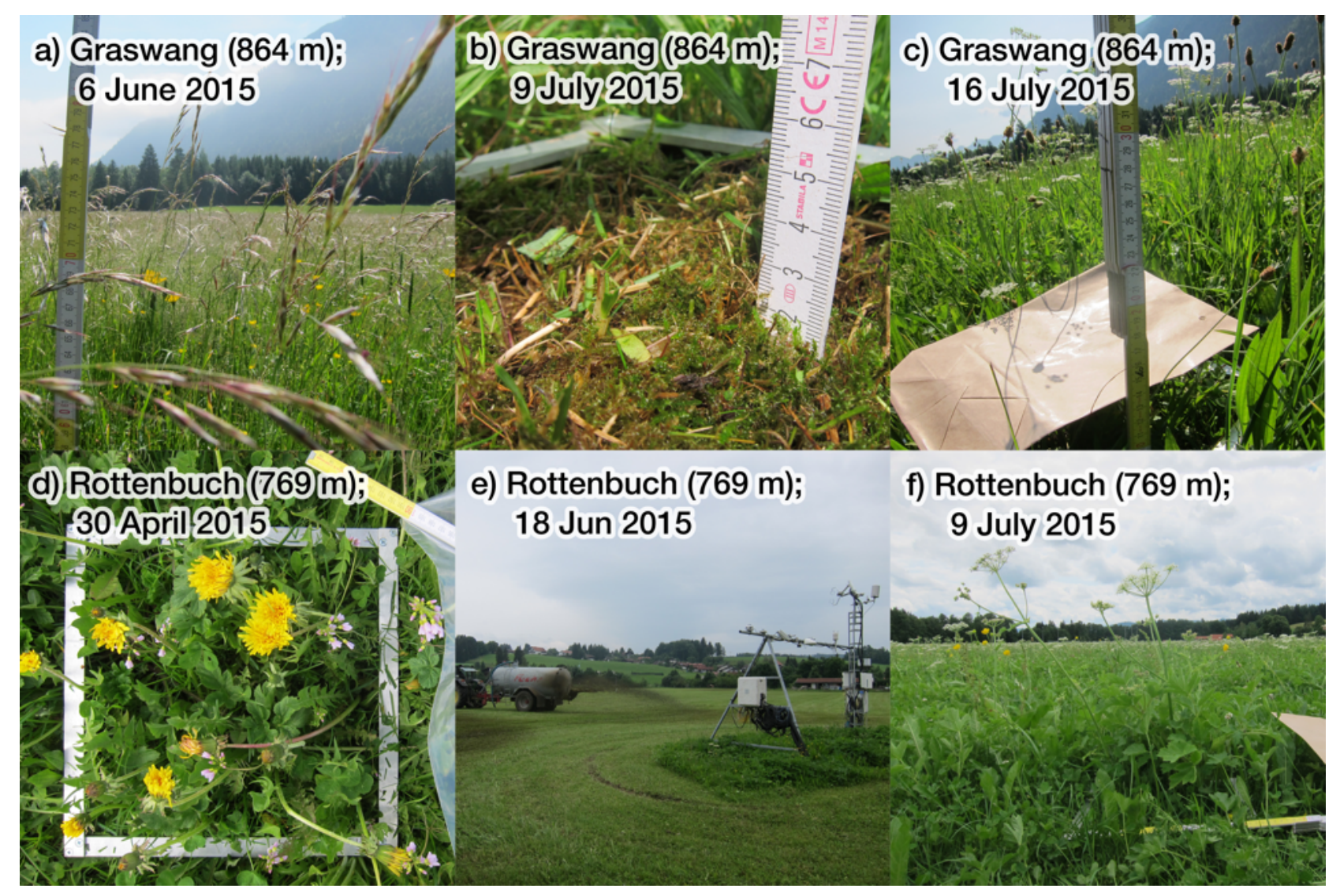

Figure C.15: The above ground part of managed grassland vegetation goes through many transformations during the season. See text for details. 


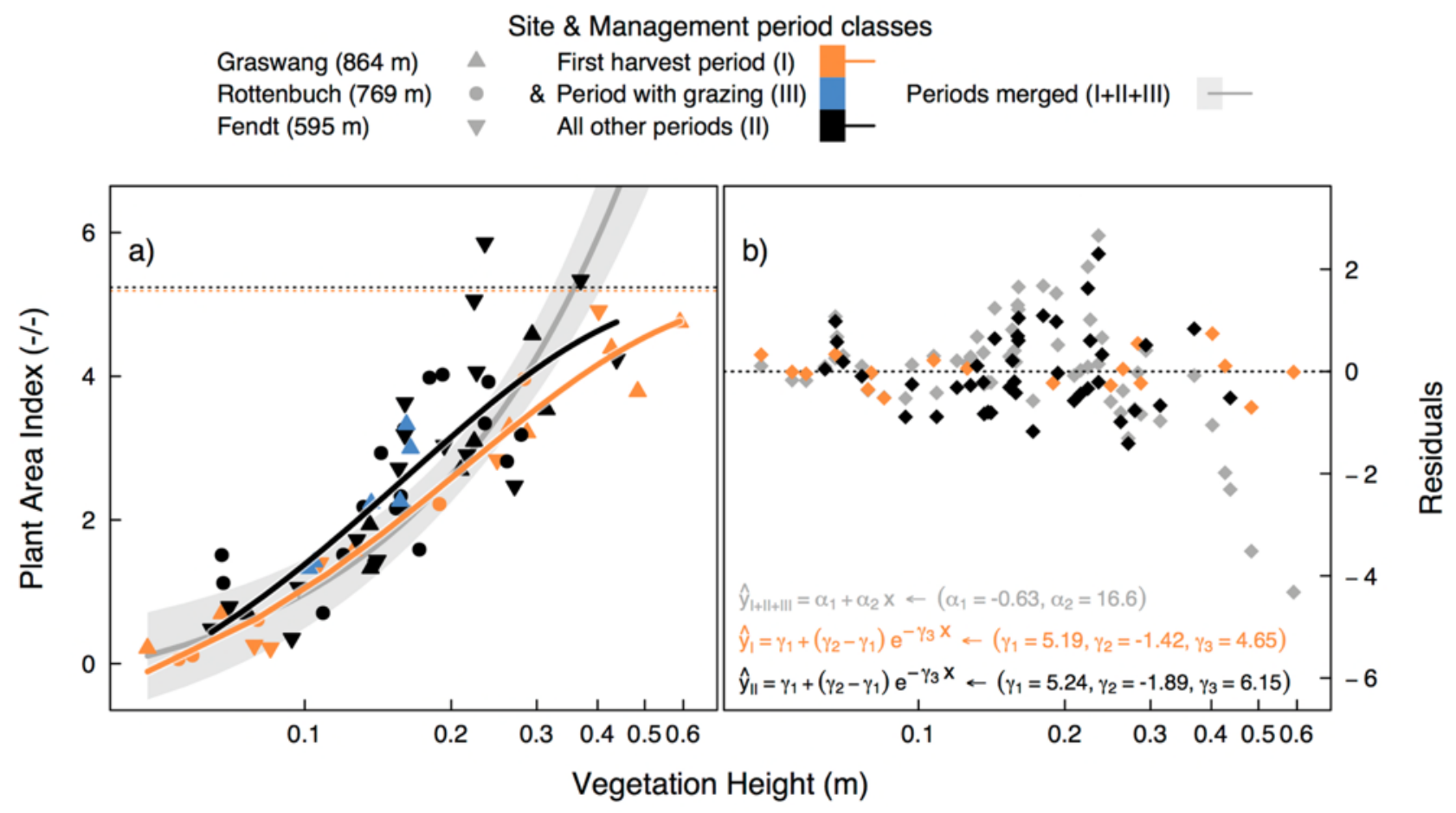

Figure D.16: The vegetation height is shown together with the respective fit model results for all sites combined per management period class against $\mathbf{a} / \mathbf{b}$ ) the plant 5 area index. The model fits are shown in part with $95 \%$-confidence interval (line \& envelope) in the left panel, together with the model residuals (diamond) and model parameters in the right panel. The asymptote values $\left(\gamma_{1}\right)$ in the right panel are shown as horizontal dotted lines in left panel. See text for details. 
Site \& Management period classes

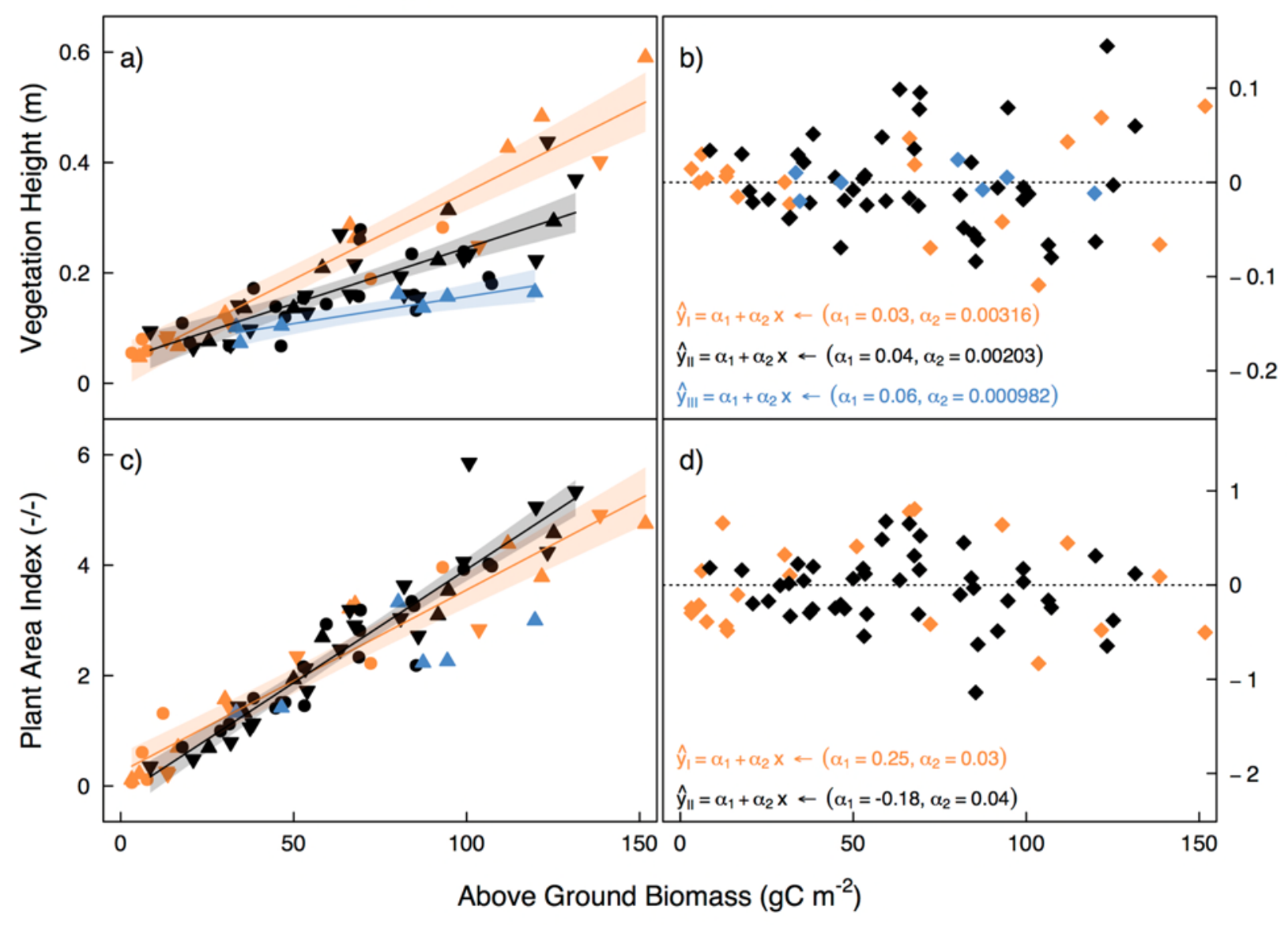

Figure D.17: The above ground biomass is shown together with fit model results for all sites combined and per management period class and against $a / b)$ the vegetation height, c/d) the plant area index. The model fits are shown with $95 \%$-confidence

5 interval (line \& envelope) in the left panels, together with the model residuals (diamond) and model parameters in the right panels. 